

\section{DISCLAIMER}

This report was prepared as an account of work sponsored by an agency of the United States Government. Neither the United States Government nor any agency Thereof, nor any of their employees, makes any warranty, express or implied, or assumes any legal liability or responsibility for the accuracy, completeness, or usefulness of any information, apparatus, product, or process disclosed, or represents that its use would not infringe privately owned rights. Reference herein to any specific commercial product, process, or service by trade name, trademark, manufacturer, or otherwise does not necessarily constitute or imply its endorsement, recommendation, or favoring by the United States Government or any agency thereof. The views and opinions of authors expressed herein do not necessarily state or reflect those of the United States Government or any agency thereof. 


\section{DISCLAIMER}

Portions of this document may be illegible in electronic image products. Images are produced from the best available original document. 
Issued by Sandia National Laboratories, operated for the United States Department of Energy by Sandia Corporation.

NOTICE : This report was prepared as an account of work sponsored by an agency of the United States Goyernment. Neither the United States Government nor any agency thereof, employees, makes any warranty, express or implied, or assumes any legal liability or responsibility for the accuracy, completeness, or usefulness of any information, apparatus, product, or process disclosed, or represents that its use would not infringe privately owned rights. Reference herein to any specific commercial product, process, ur service imply its endorsement, any agency thereof or any of their contrators or sub expressed herein do not necessarily state or subfor Government, any agency thereof or any of their contractors or subcontractors.

Printed in the United States of America Available from

National Technical Information Service

U.S. Department of Commerce

5285 Port Royal Road

Springfield, VA 22161

NTIS price codes

Printed copy: $\$ 6.00$

Microfiche copy: A01 
SAND80-0599

Unlimited Release

Printed September 1980
Distribution

Category UC-62b

\title{
PERFORMANCE OF A SOLAR-HEATED ASSEMBLY BUILDING AT SANDIA NATIONAL LABORATORIES
}

Dale E. Haskins

Experimental Systems Operations Division 4721

Sandia National Laboratories

Albuquerque, NM 87185

\begin{abstract}
This report describes the passive solar-heating system of the assembly building at Sandia National Laboratories' Photovoltaic Advanced Systems Test Facility, and gives the thermal analysis of the building. Performance predictions are also given, and actual performance for December 1979 and January 1980 are shown.
\end{abstract}




\section{ACKNOWLEDGMENT}

The performance of the assembly building's passive heating system described in this report is the result of the work of several people and organizations.

The architectural and engineering firm of Gordon Herkenhoff \& Associates made the initial building design tradeoffs which led to the selection of the water wall passive solar heating system for the building. They also generated the additional building structural cost data used in this report as the basis for cost tradeoffs in cheir design studies. These same data, with adjustments to correct for late design changes, are used to determine the cost of the water wall addition to the building.

Personnel in the Plant Engineering Department at Sandia National Laboratories contributed to the final building design by participating in the decision-making processes during the design tradeoff stages.

The research and technical writing for this report were done under contract to Sandia National Laboratories by Tech Reps, Inc. of Albuquerque, New Mexico. 


\section{CONTENTS}

$\underline{\text { Page }}$

Introduction

Description of the Building

Plans

Wa11s 10

Roof and Ceiling 14

Floor and Foundation

Water Wall (Thermal Storage System)

Auxiliary Heat

Lighting

Domestic Hot Water

Operation

C1imate

Thermal Analysis

20

Building Load Coefficient 20

Performance Estimate $\quad 21$

Standard Metal Building Option $\quad 24$

Effect of Asphalt Apron on Thermal Performance 24

Possible Methods of Improving Solar Heating Performance 24

Costs

26

Performance

APPENDIX A--Mechod of Correction for Change in Ground Reflectance

APPENDIX B--Cost Evaluation Method $\quad 41$

References 


\section{ILLUSTRATIONS}

Figure

$\underline{\text { Page }}$

$1 \quad$ Floor Plan of Assembly Building

2 South Elevation of Assembly Building

3 Cross Section of Assembly Building

$4 \quad$ Completed Assembly Building 13

5 Detail of Foundation Footing 14

6 Water Storage Tubes Set in Place Prior to Installation of Glazing 16

$7 \quad$ View of Base of Containers Before Painting 16

8 Completed Installation of Water Tubes 17

9 Temperature Distribution Pattern for Albuquerque 18

10 Annual Degree Days as a Function of Base Temperature (Albuquerque Data) 20

11 Electrical Energy Price Rise Predictions 29

12 Data Recorded at Assembly Building, December 24-29, $1979 \quad 31$

13 Data Recorded at Assembly Building, January 20-25, $1980 \quad 31$

14 Number of llours Within Each $5^{\circ} \mathrm{F}$ Temperature Brackel for December 1979

15 Number of Hours Within Each $5^{\circ} \mathrm{F}$ Temperature Bracket for January 1980 


\section{TABLES}

$\underline{\text { Table }}$

$\underline{\text { Page }}$

1

Basic Information

Climate and Insolation Summary

3 Degree Days per Month, $10^{\circ} \mathrm{C}\left(50^{\circ} \mathrm{F}\right)$ Base Temperature (Albuquerque Data)

Building Load Coefficient Computation

Computations for Annual Solar Heating Fraction

Effect of Asphalt Apron (Reflectance $=0.05$ )

on the Annual. SHF

Effect of Specular Reflector $(\rho=0.8)$ on the Annual SHF

Maximum Effect of Whitewash $\left(\rho_{g}^{\prime}=0.6\right)$ on the Annual SHF

9 Cost Estimate for Standard Metal Building

11 Levelled Annual Energy Cost for ElectricHeated, Standard Metal Building

12 Computation of Solar Heating Fraction for December 1979 and January 1980 
$8 a$ 


\section{PERFORMANCE OF A SOLAR-HEATED ASSEMBLY BUILDING AT}

SANDIA NATIONAL LABORATORIES

\section{Introduction}

The assembly building at Sandia National Laboratories' Photovoltaic Advanced Systems Test Facility derives all its space heat from passive solar energy. The building does not have an auxiliary heating system.

The great potential for energy conservation offered by passive solar systems makes the thermal performance of the building a matter of special interest. The purposes of this report are to describe the design of the building, review the thermal analyses used to predict the performance of the building, make a cost comparison with a standard metal building, and present performance data for the first winter. Basic information is given in Table 1.

\section{Description of the Building}

\section{P1ans}

The floor plan, south elevation, and a cross section of the building are shown in Figures 1, 2, and 3, respectively. The building is a standard, preengineered, metal structure (butler building) erected on a concrete floor slab on grade. Figure 4 is a photograph of the completed building . 
The steel frame walls are sheathed on the outside with 26-gauge, galvanized steel panels with a prefinished exterior surface. The inside is sheathed with 29-gauge, prefinished, white liner panels. The wall cavity is insulated with $7.5-\mathrm{cm}$ (3-in.) fiberglass batt taped to the inside face of the metal siding. The west wall is penetrated by one $0.9 \times$ 2.1-m ( $3 \times 7-f t)$ hollow, metal frame door and one $2.7 \times 3.7-m(9 \times 12-f t)$ insulated, metal overhead door. The east wall is penetrated by one $0.9 \mathrm{x}$ $2.1-\mathrm{m}$ ( $3 \times 7 \mathrm{ft})$ hollow, metal frame door. There are no penetrations in the north wall. The south wall incorporates the solar collector described below.

Table 1

Basic Information

Type of Construction

Dimensions

Floor Area

Heating System

Auxiliary Heating System

Location

Geographic Coordinates

Elevation

Architect/Engineer

Qwner
Preengineered, metal, highbay butler building

$7.6 \times 15.2 \times 4 \mathrm{mhigh}(25 \times 50 \times 13 \mathrm{ft}$ high)

$116 \mathrm{~m}^{2}\left(1250 \mathrm{ft}^{2}\right)$

Passive solar water wall

None

Photovoltaic Advanced Systems Test Facility Sandia National Laboratories

Albuquerque, NM

$35^{\circ} 03^{\prime} \mathrm{N}, 106^{\circ} 33^{\prime} \mathrm{W}$

$1676 \mathrm{~m}(5500 \mathrm{ft})$

Gordon Herkenhoff \& Associates, Inc

Sandia National Laboratories, Albuquerque, NM 


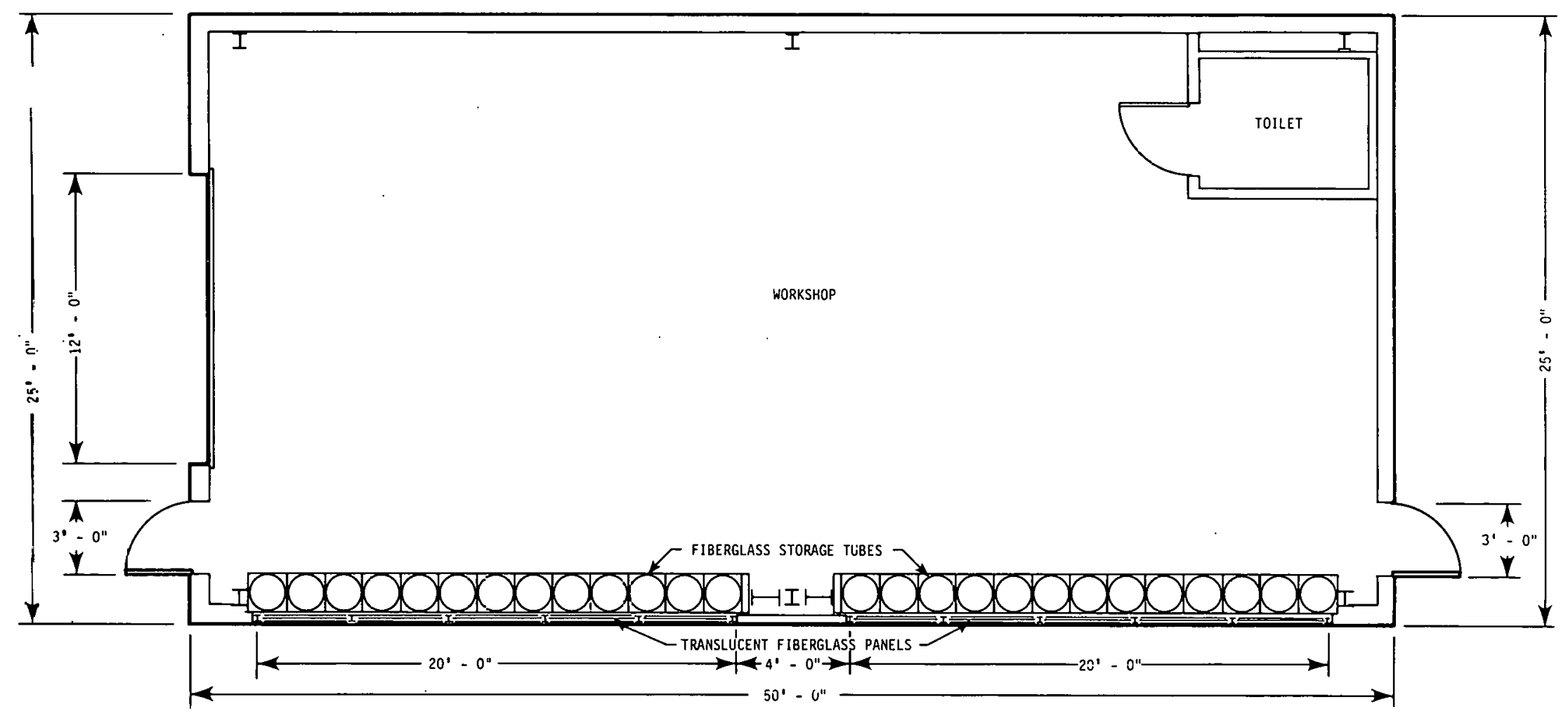

FLOOR PLAN

Figure 1. Floor Plan of Assembly Building 


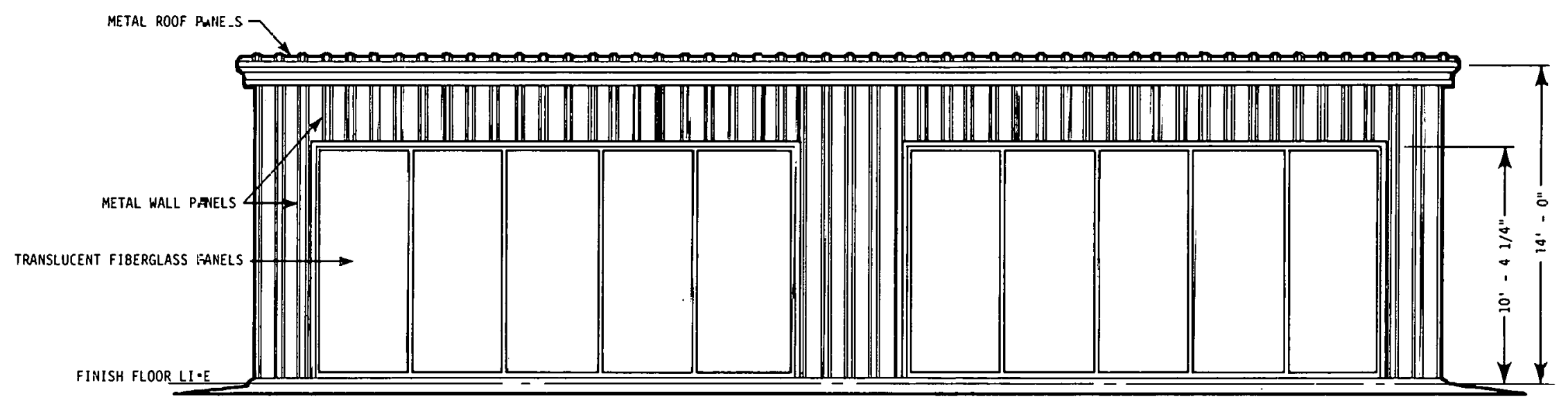

SOU־-1 ELEVAT:ON

Figare 2. Sou=h Elevation of Assembly Euilding 


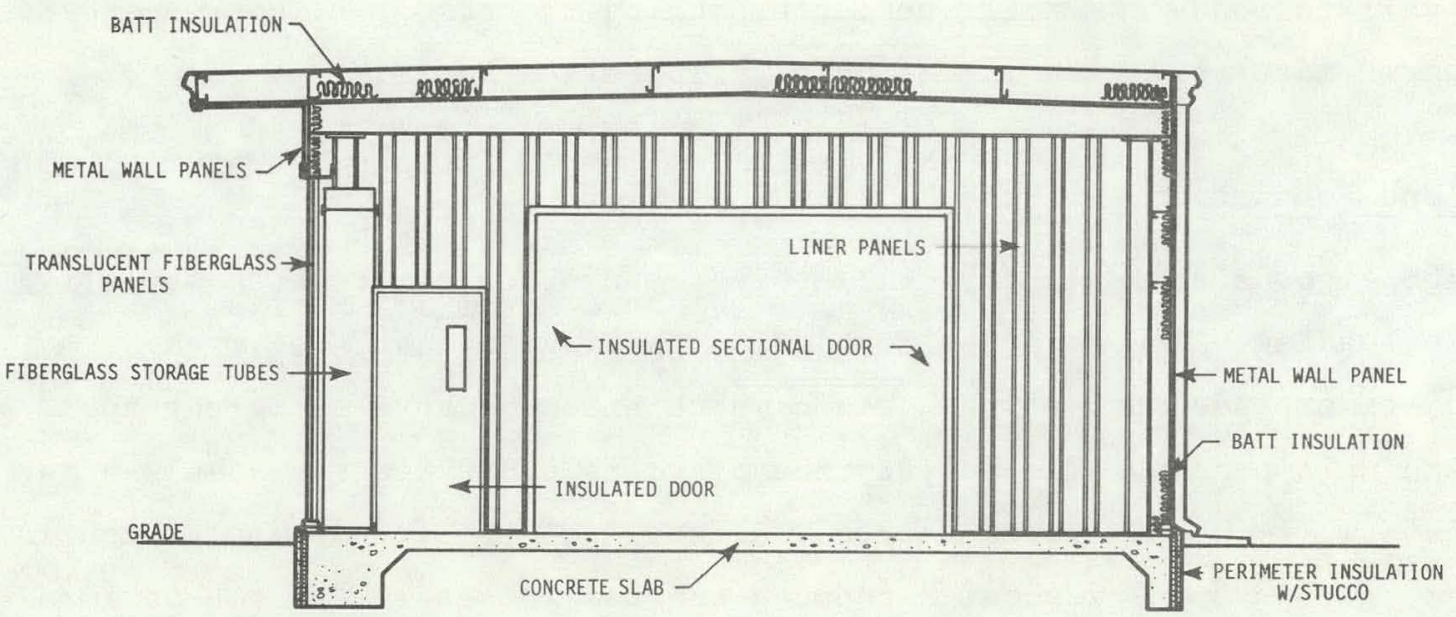

BUILDING SECTION

Figure 3. Cross Section of Assembly Building

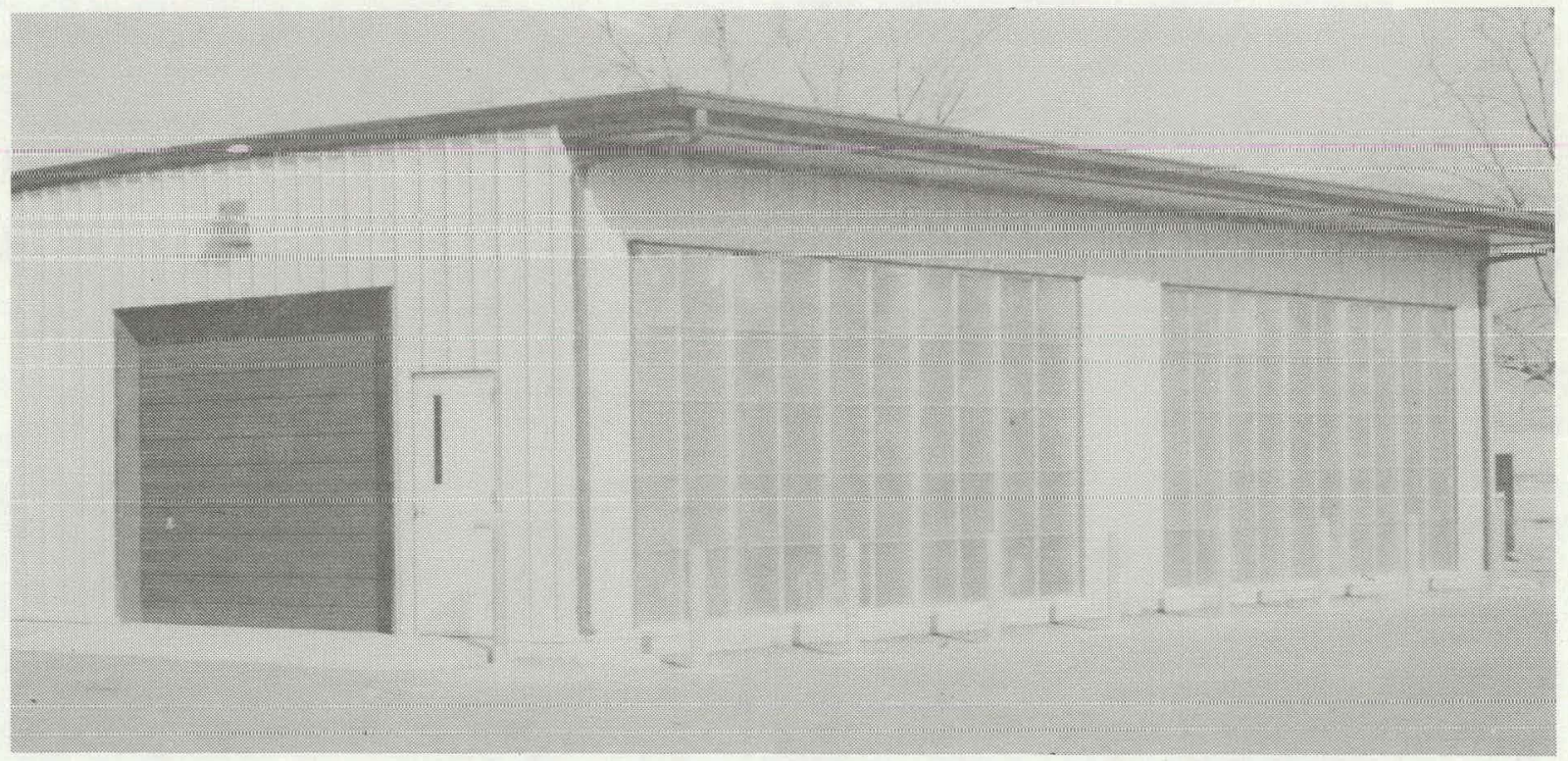

Figure 4. Completed Assembly Building 
$\underline{\text { Roof and Ceiling }}$

The roof is 26-gauge galvanized steel with a prefinished, colored exterior. The roof has a $0.9-\mathrm{m}(3-\mathrm{ft})$ eave extension overhanging the south wall to shade the solar collector during the summer. The suspended ceiling is insulated with $15-\mathrm{cm}$ (6-in.) fiberglass batts.

\section{Floor and Foundation}

The floor slab is $15-\mathrm{cm}(6-i n)-.t h i c k$ reinforced concrete to support vehicle loading. The concrete foundation footing is insulated with $5 \mathrm{~cm}$ (2 in.) of expanded polystyrene board which extends above the grade to meet the wall panels. The polystyrene board is protected from the weather by a $2.5-\mathrm{cm}$ (1-in.) layer of stucco. A detail of the foundation design is shown in Figure 5. This design reduces thermal losses around the perimeter. However, no thermal break is provided in the concrete floor s1ab where it passes under the overhead door.

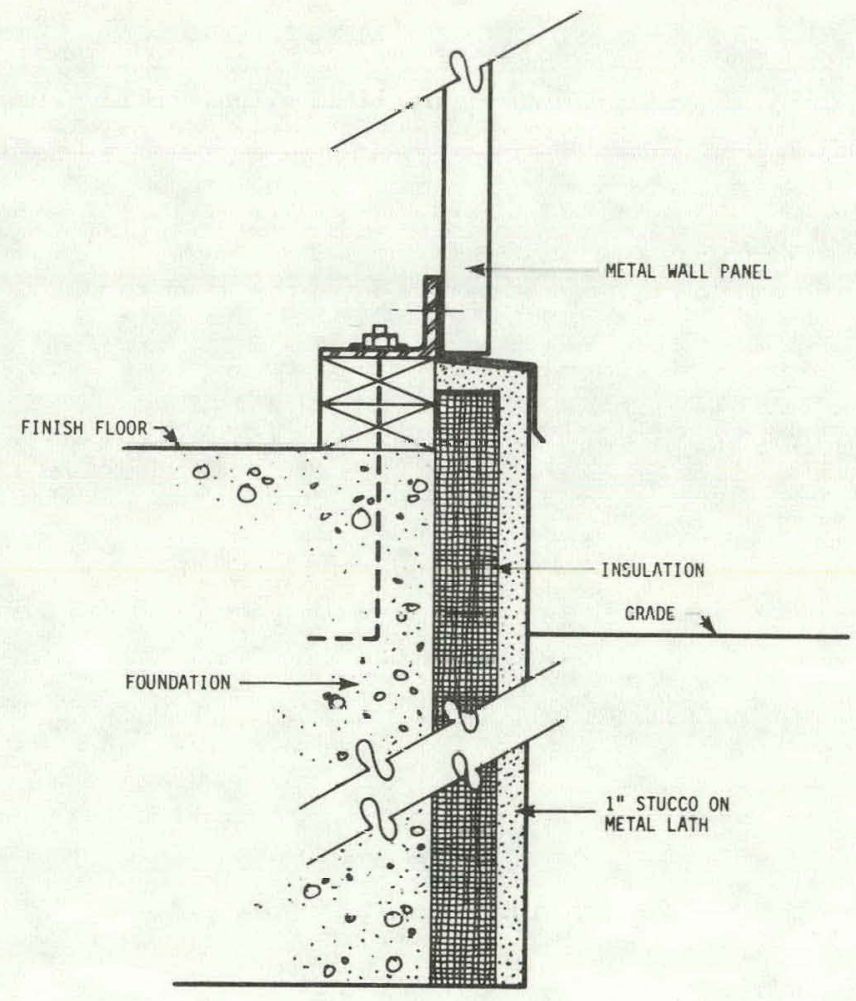

Figure 5. Detail of Foundation Footing 
Water Wall (Therma1 Storage System)

The solar collector for the assembly building is a water wa11 built as an integral part of the building's south wall. Two $3 \times 6-m$ (10 $\times 20-$ ft) openings are cut into the south wall. The openings are glazed with SUNWALL ${ }^{\circledR}$ panels manufactured by the Kalwa11 Corporation, Manchester, N.H. Extruded aluminum grids form the cores of the panels. Sheets of fiberglass-reinforced polymer, $1 \mathrm{~mm}$ (0.04 in.) thick, are pressure-bonded on each side of the grid cores. Each panel measures $1.2 \times 3.0-\mathrm{m}(4 \mathrm{x} 10 \mathrm{ft})$. The panels are $3.8 \mathrm{~cm}(1-1 / 2 \mathrm{in.})$ thick. Ten of these panels are mounted in the water wall for a total area of $37 \mathrm{~m}^{2}\left(400 \mathrm{ft}^{2}\right)$. The solar transmissivity of this panel is reported to be

$$
\begin{aligned}
& 77 \% \text { at } 0 \text {-deg angle of incidence } \\
& 73 \% \text { at } 30-\mathrm{deg} \text { ang } 1 \text { e of incidence } \\
& 65 \% \text { at } 45-\mathrm{deg} \text { ang } 1 \text { e of incidence } \\
& 48 \% \text { at } 60-\mathrm{deg} \text { angle of incidence }
\end{aligned}
$$

The water storage tubes are mounted directly behind the glazing panels. Each tube is nominally $46 \mathrm{~cm}$ (18 in.) in diameter and $3 \mathrm{~m}$ (10 ft) tal1, with a storage volume of $0.5 \mathrm{~m}^{3}\left(17.67 \mathrm{ft}^{3}\right)$. There are 26 of these water storage tubes, giving a total storage capacity of $13,000 \mathrm{~kg}(28,660$ 1b) of water. The tubes are made of fiberglass-reinforced polymer sheets with sealed bottoms and fiberglass caps and are painted on the exterior with flat black latex paint. Photographs of the water storage tubes as seen during the construction of the building are shown in Figures 6,7 , and 8 .

\section{Auxiliary Heat}

The assembly building does not have an auxiliary heating system.

\section{Lighting}

Six halogen lamps light the interior. They consume approximately 100 w each. 


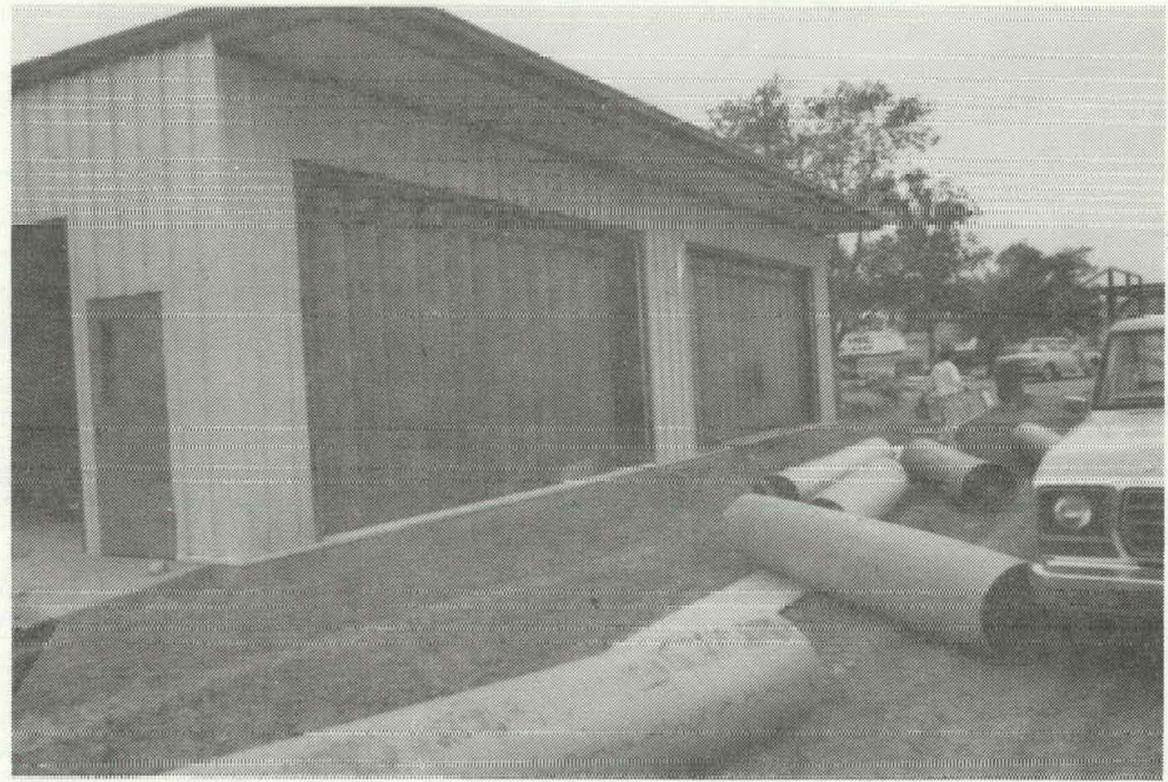

Figure 6. Water Storage Tubes Set in Place Prior to Installation of Glazing (Tubes are not yet painted black. Fiberboard shipping containers are 1ying in the foreground.)

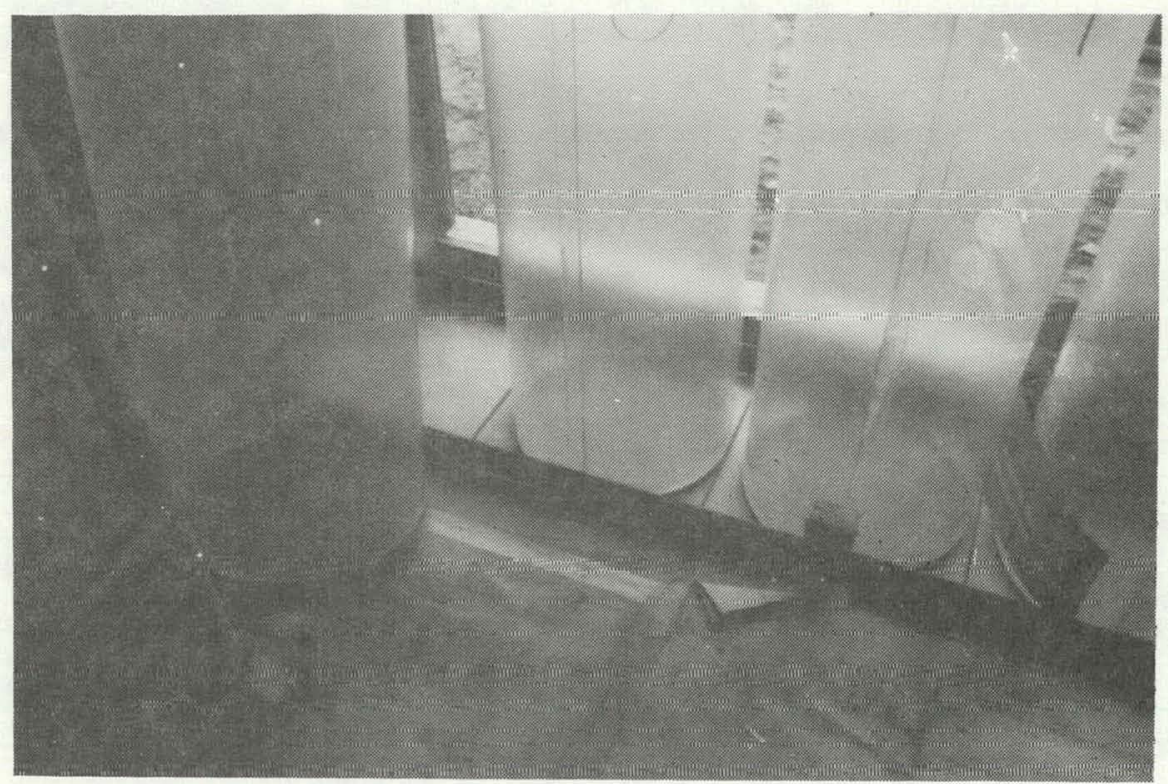

Figure 7. View of Base of Containers Before Painting 


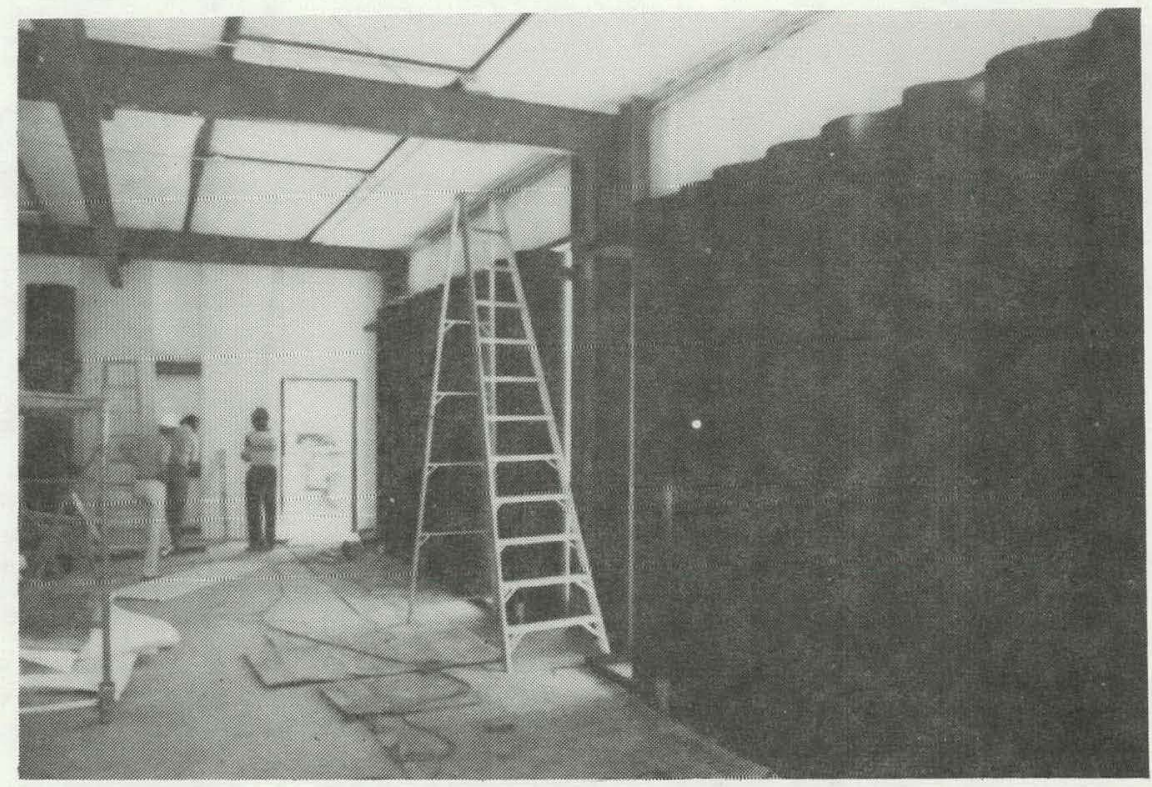

Figure 8. Completed Installation of Water Tubes

\section{Domestic Hot Water}

The bathroom in the northeast corner of the building includes a hot water heater. In accordance with Sandia's energy conservation policies, the hot water heater has been turned off and consumes no energy.

\section{Operation}

Solar radiation transmitted through the glazing on the snuth wall is absorbed on the black-painted surfaces of the water storage tubes. The heat is conducted through the tube wall to the water within the tube. Convection currents move the heated water so that the tube surfaces facing the interior work space become warm. Heat is transferred to the workspace by radiation and by air convection currents. There are no temperature controls for the system. Temperature moderation is dependent on the design and balancing of the thermal components (e.g., the glazing area on the south wall, the thermal mass in the water tubes, building insulation and heat loss rate, ambient temperature, and solar insolation). 
The design of a solar-heated building is strongly dependent on the local weather conditions and on the availability of solar energy. Table 2 is a climate and insolation summary extracted from References 1 and 2 .

The "degree days" (DD) shown in Table 2 refer to a base temperature of $18^{\circ} \mathrm{C}\left(65^{\circ} \mathrm{F}\right)$. Because of the working environment, the design temperature selected for the interior of the building was $10^{\circ} \mathrm{C}\left(50^{\circ} \mathrm{F}\right)$, so new degree-day data was computed. Ambient temperature data for this purpose was extracted from Reference 3. A yearly summary of the hourly temperatures is shown in Figure 9.

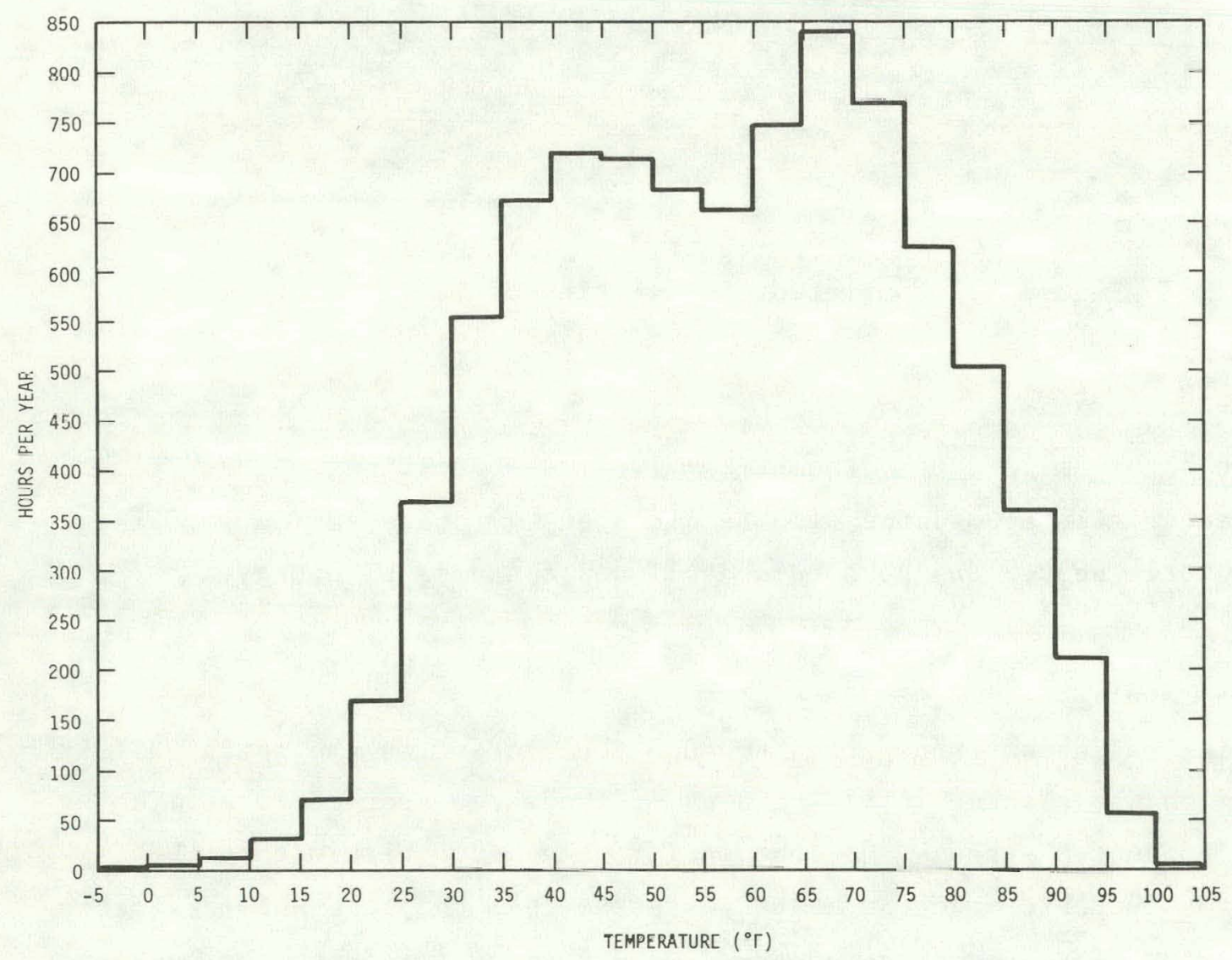

Figure 9. Temperature Distribution Pattern for Albuquerque

The number of degree days rapidly decreases as the base temperature is reduced. The relationship is shown in Figure 10. The degree days per month for the months November through April (the heating season in Albuquerque) for a $10^{\circ} \mathrm{C}\left(50^{\circ} \mathrm{F}\right)$ base temperature are given in Table 3 . 
Table 2

Climate and Insolation Summary

Site Name--Albuquerque, N.M. Latitude--35.050 Longitude--106.620

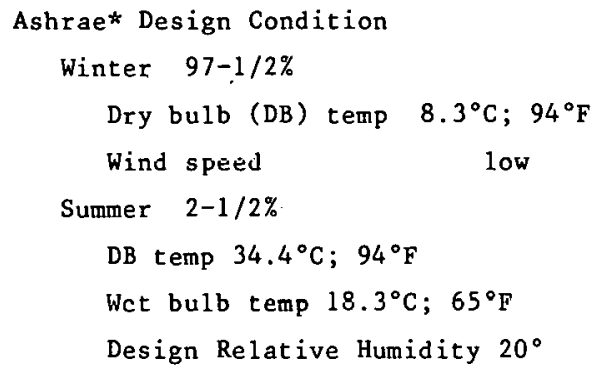

*American Society. of Heating, Refrigerating, and Airconditioning Engineers 


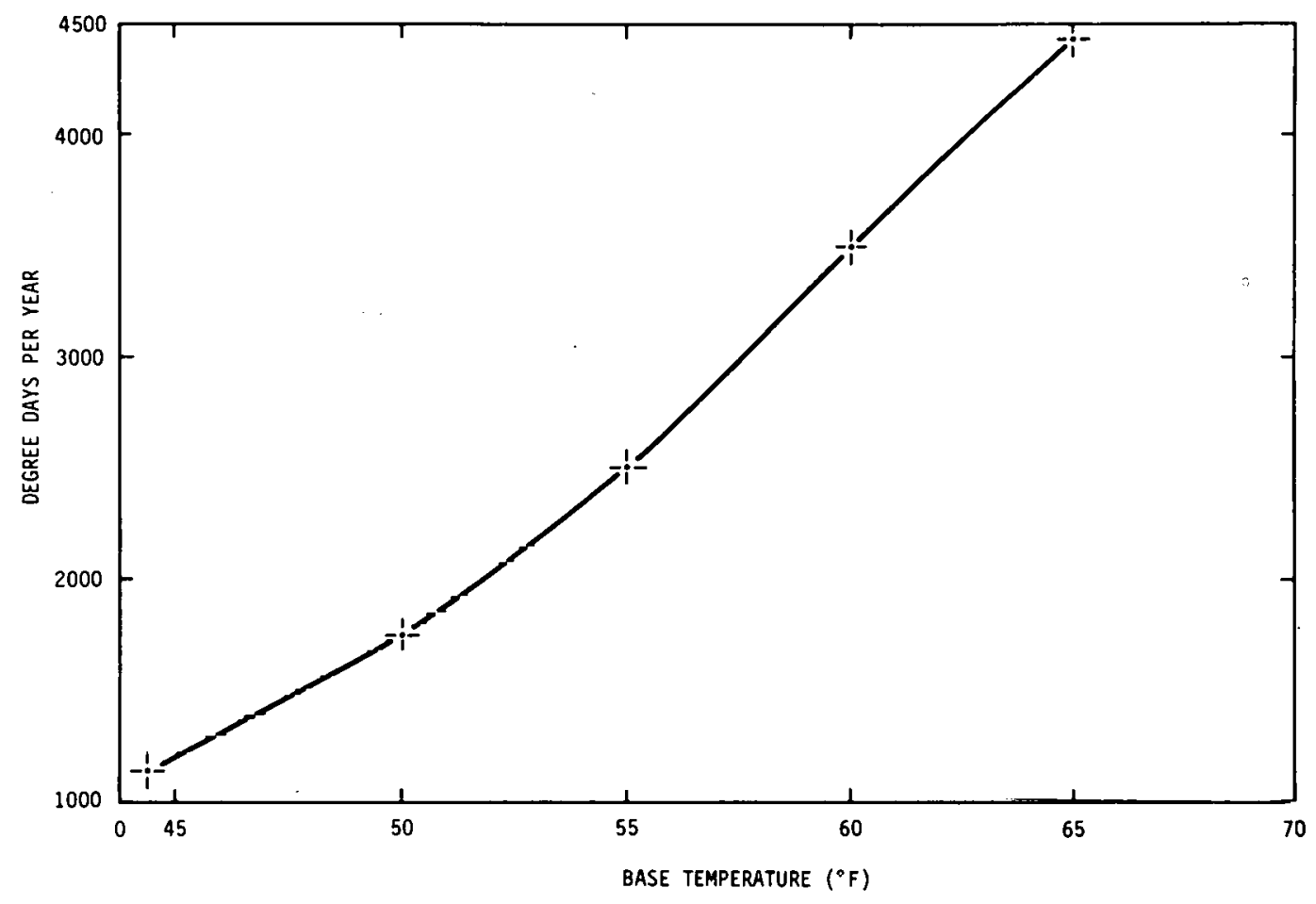

Figure 10. Annual Degree Days as a Function of Base Temperature (Albuquerque Data)

Table 3
Degree Days per Month, $10^{\circ} \mathrm{C}\left(50^{\circ} \mathrm{F}\right)$ Base Temperature (Albuquerque Data)

\begin{tabular}{llllllll} 
& Nov & Déc & Jan & Feb & Mar & \multicolumn{1}{c}{ pr } & Annua 1* \\
${ }^{\circ} \mathrm{C}$ & 131 & 244 & 253 & 173 & 118 & 37 & 987
\end{tabular}

Degree Days

$\begin{array}{llllllll}{ }^{\circ} \mathrm{F} & 236 & 439 & 455 & 312 & 212 & 66 & 1777\end{array}$

*Includes degree days not shown in Nov-Apr columns

Thermal Analysis

Building Load Coefficient

The building load coefficient (BLC) quantifies the rate at which a building loses heat or the additional energy required to increase the building temperature one additional degree. The BLC for the assembly 
building is $8052 \mathrm{~W} \cdot \mathrm{h} / \mathrm{DD}(15264 \mathrm{Btu} / \mathrm{DD})$. The computations are shown in Table 4 .

Table 4

Building Load Coefficient Computation

\begin{tabular}{|c|c|c|c|c|c|c|}
\hline \multirow[b]{2}{*}{ Surface } & \multicolumn{2}{|c|}{ Area } & \multicolumn{2}{|c|}{ U-Value } & \multicolumn{2}{|c|}{$\mathrm{U} \times \mathrm{A}$} \\
\hline & $\mathrm{m}^{2}$ & $\left(\mathrm{ft}^{2}\right)$ & $\mathrm{W} / \mathrm{m}^{2} \cdot{ }^{\circ} \mathrm{C}$ & $\left(\mathrm{Btu} / \mathrm{ft}^{2} \cdot{ }^{\circ} \mathrm{F} \cdot \mathrm{h}\right)$ & $\mathrm{W} /{ }^{\circ} \mathrm{C}$ & Btu $\left./{ }^{\circ} \mathrm{F} . \mathrm{h}\right)$ \\
\hline Water wall & 37 & $(400)$ & 1.87 & $(0.33)$ & 70 & $(132)$ \\
\hline Opaque walls & 129 & $(1388)$ & 0.51 & $(0.09)$ & 56 & (125) \\
\hline Ceiling & 116 & $(1250)$ & 0.28 & $(0.05)$ & 33 & (63) \\
\hline Floor* & -- & -- & -- & -- & -- & -- \\
\hline Ro11ing door & 11 & $(120)$ & 0.62 & $(0.11)$ & 7 & (13) \\
\hline Personnel doors & 4 & (42) & 1.36 & $(0.24)$ & 5 & $(10)$ \\
\hline & & & lding $s k$ & n conductance $=$ & 181 & (343) \\
\hline
\end{tabular}

Because of the difficulties associated with sealing the rolling door, building infiltration is expected to be one air change per hour.

$$
\begin{aligned}
\text { Infiltration }=16,250 \mathrm{ft} \times 1 \times 0.018 & =155 \\
& =336
\end{aligned}
$$

\footnotetext{
Modified BLC $=8064$ Wh $/ \mathrm{DD}(15,264 \mathrm{Btu} / \mathrm{DD})$

Unmodified $\mathrm{BLC}=6384 \mathrm{Wh} / \mathrm{DD}(12,096 \mathrm{Btu} / \mathrm{DD})$
}

\section{Performance Estimate}

Los Alamos Scientific Laboratory has developed methods for estimating the annual solar heating performance of a building using a water wall thermal storage system. ${ }^{4}$ The method has been applied to the assembly building and indicates that $91 \%$ of the annual building heat load will be provided by solar heat. Conversely, $9 \%$ of the annual building heat load 
must be supplied by auxiliary heating sources. Since the building does not have an auxiliary heat source, the temperature is expected occasionally to fall below the design temperature of $10^{\circ} \mathrm{C}\left(50^{\circ} \mathrm{F}\right.$.) The computations for this estimate are given in Table 5. The column entries in Tables 5 through 8 are described below:

Column 1: The month of the year

Column 2: The number of degree days in the month. In this case, a $10^{\circ} \mathrm{C}\left(50^{\circ} \mathrm{F}\right)$ base temperature is used.

Column 3: The building heat load for the month, obtained by multiplying Column 2 by the BLC (in this case, BLC $=15$ $264 \mathrm{Dti} / \mathrm{DD})$. Tt shuild be nuted that Reference 4 defines the load coefficient for the entire building as the "MODIFIED BLC." If the losses through the solar collector are ignored, the resulting coefficient is defined as the "UNmodified BLC."

Column 4: The total monthly solar radiation incident on $1 \mathrm{ft}^{2}$ of horizontal surface. This figure is extracted from available tables.

Column 5: The latitude (L) at the location of the building minus the sun's declination $(\delta)$ at midmonth.

Column 6: The solar radiation absorbed by the solar collector. This entry is derived from the entries in Columns 4 and 5 by an empirical relationship given in Reference 4.

Column 7: The ratio of the entry in Column 6 to the entry in Column 3 .

Column 8: The fraction of the monthly heating load (Column 3) supplied by solar heat. This entry is derived from the solar load ratio (SLR) (Column 7) by a second empirical relationship given in Reference 4 .

Column 9: The energy needed from an auxiliary heating system to keep the building at the design temperature of $10^{\circ} \mathrm{C}\left(50^{\circ} \mathrm{F}\right)$. 
Table 5

Computations for the Annual Solar Heating Fraction

\begin{tabular}{|c|c|c|c|c|c|c|c|c|c|c|c|c|}
\hline$\underline{1}$ & & $\underline{2}$ & & $\underline{3}$ & & $\underline{4}$ & $\underline{5}$ & $\underline{6}$ & & $\underline{8}$ & & $\underline{9}$ \\
\hline \multirow[b]{2}{*}{ Month } & \multirow{2}{*}{$\begin{array}{l}\text { Degree } \\
{ }^{\circ} \mathrm{C} \\
\end{array}$} & \multirow{2}{*}{$\begin{array}{l}\text { Days } \\
\left({ }^{\circ} \mathrm{F}\right)\end{array}$} & \multicolumn{2}{|c|}{ Yonthly Load } & \multicolumn{2}{|c|}{$\begin{array}{l}\text { Tetal Solar Radiation } \\
\text { on Horizontal Surface }\end{array}$} & \multirow{2}{*}{$\begin{array}{l}\text { Latitude Minus } \\
\text { Sun Declimation } \\
\text { (Degrees) } \\
\end{array}$} & \multicolumn{2}{|c|}{$\begin{array}{l}\text { Solar Radiation } \\
\text { Absorbed by } \\
\text { Solar Collector }\end{array}$} & \multirow{2}{*}{$\begin{array}{c}\text { Solar Heating } \\
\text { Fraction } \\
\text { SHF } \\
\end{array}$} & \multicolumn{2}{|c|}{$\begin{array}{c}\text { Auxiliary Heater } \\
\text { Required }\end{array}$} \\
\hline & & & $\mathrm{kWh} / \mathrm{mo}$ & $(\mathrm{MBtu} / \mathrm{mo})$ & $\mathrm{kWt} / \mathrm{mo} \cdot \mathrm{m}^{2}$ & $\left(\mathrm{Btu} / \mathrm{mo} . \mathrm{ft}^{2}\right)$ & & $\mathrm{kWh} / \mathrm{mo}$ & $(\mathrm{MBtu} / \mathrm{mo})$ & & $\mathrm{kWh} / \mathrm{mo}-\mathrm{m}^{2}$ & $(\mathrm{MBtu} / \mathrm{mo})$ \\
\hline Nov & 131 & $(236)$ & 1055 & 3.502 & 117 & $(36,960)$ & 53.66 & 45,552 & $(14.44)$ & D. 998 & 0.3 & $(0.001)$ \\
\hline Dec & 244 & $(439)$ & 1963 & 6.701 & 100 & $(31,558)$ & 58.18 & 44,637 & $(14.15)$ & 0.883 & 230 & $(0.784)$ \\
\hline Jan & 253 & $(455)$ & 2035 & 6.945 & 1.10 & $(34: 375)$ & 56.50 & 46,909 & $(14.87)$ & 0.887 & 230 & $(0.785)$ \\
\hline Feb & 173 & $(312)$ & 1395 & 4.762 & 126 & $(39,872)$. & 49.07 & 42,429 & $(13.45)$ & 0.954 & 64 & $(0.219)$ \\
\hline Mar & 118 & $(212)$ & $9<8$ & 3.236 & 134 & $(58,466)$ & 37.89 & 42,208 & $(13.38)$ & 1 & 0 & $(0)$ \\
\hline \multirow[t]{2}{*}{$\Delta p r$} & 37 & $(66)$ & $2 s$ & 1.007 & 216 & $(68,400)$ & 25.95 & 31,767 & $(10.07)$ & 1 & 0 & $(0)$ \\
\hline & $956(1$ & $720)$ & & & & & & & & & 524.3 & $(1.789)$ \\
\hline & & & & Annual & $=1-$ & $\frac{\text { Annual Auxi }}{\text { Annual DD)(U1 }}$ & $\frac{\text { cy Energy }}{\text { ified BLC) }}=$ & 1.94 & $L=0.91$ & & & \\
\hline
\end{tabular}


If the solar heating option had not been selected for the building, a standard metal bullding of the same dimensions would have been used. The BLC for such a bullding would be $6836 \mathrm{~W} . \mathrm{h} / \mathrm{DD}(12,960 \mathrm{Btu} / \mathrm{DD})$, assuming the solar collector is replaced with wall panels. Annual fuel consumption for this building would be $6533 \mathrm{~kW} . \mathrm{h}$ (22.3 MBtu). Because no auxiliary heating system is included in the assembly building, this figure represents the annual energy savings. However, it is expected that the assembly building occasionally may drop below the design temperature while the "ctandard" metal. building would not, at least as long as fuel is avai1able.

Effect of Aspialt Apron on Thermal Performance

An extensive area of black asphalt paving lies on the south side of the assembly building. The reflectance of the asphalt $(g)$ is estimated at 0.05 which is less than the ground reflectance of 0.3 used in Reference 4. Columns $2,3,4$, and 5 are omitted from Table 6 because llie data in those columns are identical to those in Table 5. The data show a reduction of only $2 \%$ in the annual solar heating fraction (SHF) due to the poor reflectance of the asphalt. However, the annual auxiliary heating requirement is increased by $30 \%$ which would be significant if the assembly building were provided with auxiliary hear.

\section{Possible Methods of Improving Solar Heating Performance}

Reference 4 furnishes a method for estimating the enhancement of performance when specular reflectors are placed on the ground in the front of the solar wall. The reflectors considered must be the same dimensions as the glazing on the solar wall and must be placed horizontally, adjacent to the vertical glazing. The reflectance is specified as 0.8 . For the assembly bullding, these standards require that two reflectors, each $3 \times 6.1 \mathrm{~m}$ (10 x $20 \mathrm{ft}$ ), be placed flat on the asphalt on the south side of the solar wa11. The.results of applying this correction are shown in Table 7. The reflectors increase the amount of radiation absorbed by the wall (Appendix A). The computation indicates an annual SHF of $96 \%$, an increase of $7 \%$ over the plain asphalt case (Table 6). 
Table 6

Effect of Asphalt Apron (Reflectance $=0.05$ ) on the Annual SHF

\begin{tabular}{|c|c|c|c|c|c|c|}
\hline$\underline{1}$ & \multicolumn{2}{|r|}{$\underline{6}$} & ? & $\underline{8}$ & \multicolumn{2}{|c|}{$\underline{9}$} \\
\hline & \multirow[t]{2}{*}{$\begin{array}{r}\text { Solar } \\
\text { Abso } \\
\text { Solar } \\
\mathrm{kWh} / \mathrm{mo} \\
\end{array}$} & \multirow[t]{2}{*}{$\begin{array}{l}\text { Radiation } \\
\text { orbed by } \\
\text { Collector } \\
(\mathrm{MBtu} / \mathrm{mo}) \\
\end{array}$} & \multirow{2}{*}{$\begin{array}{l}\text { Solar Load } \\
\text { Ratio } \\
\text { (SLR) } \\
\end{array}$} & \multirow{2}{*}{$\begin{array}{c}\text { Solar Heating } \\
\text { Fraction } \\
\text { (SHF) }\end{array}$} & \multicolumn{2}{|c|}{$\begin{array}{c}\text { Auxiliary Heating } \\
\text { Required }\end{array}$} \\
\hline th & & & & & $\mathrm{kWh} / \mathrm{mo}$ & $(\mathrm{MBtu} / \mathrm{mo})$ \\
\hline & 38.50 & $(13.14)$ & 3.65 & 0.990 & 11 & $(0.036)$ \\
\hline & 3821 & $(13.04)$ & 1.95 & 0.858 & 279 & $(0.952)$ \\
\hline & 4000 & $(13.65)$ & 1.96 & 0.861 & 283 & $(0.965)$ \\
\hline & 3531 & $(12.05)$ & 2.53 & 0.931 & 96 & $(0.329)$ \\
\hline & 3323 & $(11.34)$ & 3.50 & 0.985 & 14 & $(0.049)$ \\
\hline & 2247 & $(7.67)$ & 7.62 & 1 & $\underline{0}$ & $(0)$ \\
\hline & & & & & 683 & $(2.33)$ \\
\hline
\end{tabular}

$$
\text { Annual SHF }=1-\frac{2.33 \times 106}{1720 \times 12096}=0.89
$$

Table 7

Effect of Specular Reflector $(\rho=0.8)$ on the Annual SHF

$$
\underline{1} \quad \underline{6} \quad \underline{7} \quad \underline{8} \quad \underline{9}
$$

Solar Radiation

Absorbed by

Solar Collector

Month

Nov

Dec

Jan

Feb

Mar

Apr $\mathrm{kWh} / \mathrm{mo}$ (MBtu/mo)

5324

5125

5470

4984

4644

2792
(18.17)

(17.49)

(18.67)

(17.01)

(15.85)

(9.53)

\section{Solar Load} Ratio (SLR)

5.04

2.61

2.67

3.57

4.90

9.46

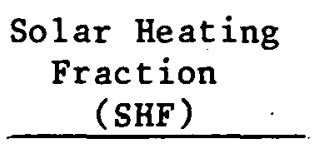

1

0.938

0.942

0.987

1

1
Auxiliary Heating Required $\mathrm{kWh} / \mathrm{mo}$ (MBtu/mo)

00

$122(0.415)$

$118(0.403)$

$18 \quad(0.062)$

00

$\frac{0}{258} \frac{0}{(0.880)}$

Annual $\mathrm{SHF}=1-\frac{0.880 \times 10^{6}}{1720 \times 12096}=0.96$ 
Since the asphalt apron is a working area for the photovoltaic test facility and is subject to traffic, it may not be practical to lay specular reflectors there. An alternate method of improving the SHF is to whitewash the asphalt in front of the solar wall. Since reflection in this case would be diffuse, a very large area would need to be whitewashed to be effective. The maximum possible improvement attainable by whitewashing can be estimated by assuming the ground reflectance to be the same as for whitewash. Table 8 summarizes the computations for the annual SHF assuming a ground reflectance $\left(\rho_{g}^{\prime}\right)$ of 0.6 . A maximum increase of approximately $4 \%$ is indicated for the whitewash modification over the plain asphalt case,

Table 8

Maximum Effect of Whitewash $\left(p_{g}^{\prime}=0.0\right)$ on the Annul SHF

\begin{tabular}{|c|c|c|c|c|c|c|}
\hline$\underline{1}$ & & $\underline{6}$ & $\underline{7}$ & 8 & & 9 \\
\hline Month & $\begin{array}{l}\text { Solar } \\
\text { Abs } \\
\text { Solar } \\
\mathrm{kWh} / \mathrm{mo}\end{array}$ & $\begin{array}{l}\text { adiation } \\
\text { bled } \\
\text { llector } \\
\text { (MBtu/mo) }\end{array}$ & $\begin{array}{c}\text { Solar Load } \\
\text { Ratio } \\
\text { (SLR) } \\
\end{array}$ & $\begin{array}{c}\text { Solar Heating } \\
\text { Fraction } \\
\text { (SHF) } \\
\end{array}$ & $\begin{array}{r}\text { Auxilis } \\
\text { Re } \\
\mathrm{kWh} / \mathrm{mo}\end{array}$ & $\begin{array}{l}\text { ry Heating } \\
\text { quired } \\
(\mathrm{MBtu} / \mathrm{mo})\end{array}$ \\
\hline Nov & 4685 & $(15.99)$ & 4.44 & 1 & 0 & 0 \\
\hline Dec & 4533 & $(15.47)$ & 2.31 & 0.908 & 180 & $(0,616)$ \\
\hline Jan & 4785 & $(16.33)$ & 2.35 & 0.913 & 177 & $(0.604)$ \\
\hline Feb & 4430 & $(15.12)$ & 3.18 & 0.973 & 38 & $(0.129)$ \\
\hline Mar & 4641 & $(15.84)$ & 4.89 & 1 & 0 & 0 \\
\hline & & & & & 395 & $(1.349)$ \\
\hline
\end{tabular}

Annual $\mathrm{SHF}=0.935$

Costs

Prior to construction of the assembly building, cost estimates were made for a standard metal butler building with an electric heating system and for several alternate forms of solar-heated buildings. The water wall solar-heated building was shown to be the least costly of the alternate forms. The cost estimates for the standard building and the water wall 
solar-heated building are shown in Tables 9 and 10 . Common items (e.g., foundation, slab floor, grading) have been omitted from these estimates since they do not affect the cost differential between the two types of buildings. The tables show that the solar option cost $\$ 4511.00$ more than a standard metal building with electric heat.

The standard building costs less to bulld but there is an annual heating bill which must be paid over the lifetime of the building. An evaluation of the economics of buying the solar option instead of the standard building (with electric heat) must consider both the additional capital costs of the solar option, $\$ 4511.00$, and the annual heating costs for the standard building. The method chosen here to make the comparison is the one used by the Office of Technology Assessment, Congress of the United States. 5 The essential aspects of the method are shown in Appendix $B$.

Table 9

Cost Estimate for Standard Meta1 Building

\begin{tabular}{|c|c|c|c|c|}
\hline Item & Unit & Quantity & $\begin{array}{l}\text { Unit } \\
\text { Price }\end{array}$ & Amount \\
\hline $\begin{array}{l}\text { Bullding Shell consisting of } \\
\text { steel frame, metal siding, } \\
\text { wall and roof insulation, } \\
\text { and metal liner panel }\end{array}$ & $f t^{2}$ & 1250 & $\$ 7.50$ & $\$ 9,375.00$ \\
\hline $\begin{array}{l}\text { Electric unit heaters } \\
\text { (complete) }\end{array}$ & $\mathrm{Ea}$ & 2 & 830.00 & $1,660.00$ \\
\hline SUBTOTAL & & & & $\$ 11,035.00$ \\
\hline $5 \%$ Contingency & & & & 552.00 \\
\hline SUBTOTAL & & & & $\$ 11,587.00$ \\
\hline $\begin{array}{l}25 \% \text { Overhead, profit, tax, } \\
\text { and bond }\end{array}$ & & & & $2,897.00$ \\
\hline TOTAL & & & & $\$ 14,484.00$ \\
\hline
\end{tabular}


Cost Estimate for Solar-Heated Building

\begin{tabular}{|c|c|c|c|c|}
\hline It em & Unit & Quantity & $\begin{array}{l}\text { Unit } \\
\text { Price }\end{array}$ & Amount \\
\hline shell (see Table 9, & $f t^{2}$ & 1250 & $\$ 7.50$ & $\$ 9375.00$ \\
\hline 11 panels & $\mathrm{ft} \mathrm{t}^{2}$ & 525 & -1.30 & -68.3 .00 \\
\hline 11 insulation & $f t^{2}$ & 525 & -0.40 & -210.00 \\
\hline ll liner panel & $f t^{1}$ & 4000 & -1.00 & -400.00 \\
\hline overhang & $\begin{array}{l}\text { Linear } \\
\text { feet }\end{array}$ & 50 & 13.83 & 692.00 \\
\hline
\end{tabular}

Solar thermal storage tubes, $10 \mathrm{ft}$ long by 18 in: diameter

$\begin{array}{lrrr}\text { Ea } & 26 & 91.50 & 2379.00 \\ \text { Ea } & 26 & 7.00 & 182.00 \\ \text { Ea } & 10 & 131.50 & 1315.00 \\ \text { Ea } & 10 & 12.00 & 120.00 \\ \text { Linear } & 228 & .7 .47 & 1703.00 \\ \text { frnt } & & & \end{array}$

SUB'I'U'I'AL

$\$ 14 \quad 473.00$

$3 \%$ Contingencies

724.00

SIJRTOTAT.

$25 \%$ Overhead, profit, tax, and bond

$\$ 15197.00$

TOTAL

$\begin{array}{r}3799.00 \\ \hline 18996.00 \\ 14484.00 \\ \hline 4511.00\end{array}$

COST DIFFERENTIAL FOR SOLAR HEATED BUILDING 
The levelled capital costs of the solar option are $\$ 529.86$ per year over a period of $20 \mathrm{yrs}$. The 20-yr period for evaluation is arbitrarily selected. A discount rate (d) of $10 \%$ was used, as recommended for government agencies by the office of Management and Budget. 5

The levelled purchased energy costs were computed for two different inflation rates $(6 \%$ and $12 \%$ ) and for two different energy price escalation rates ( $2 \mathrm{X}$ and $5 \mathrm{X}$ ). The $2 \mathrm{X}$ energy price escalation rate assumes that energy prices expressed in constant 1976 dollars will eventually stabilize at a price twice what they were in 1976 (Appendix B). A similar assumption pertains for the $5 \mathrm{X}$ rate, with energy prices, expressed in constant 1976 dollars, projected to stabilize at 5 times their 1976 level. Both of these price projections are plotted in Figure 11 for 1980 through 2000, the 20-yr evaluation period. The resulting levelled purchased energy costs over the 20-yr evaluation period for each case considered are shown in Table 11 .

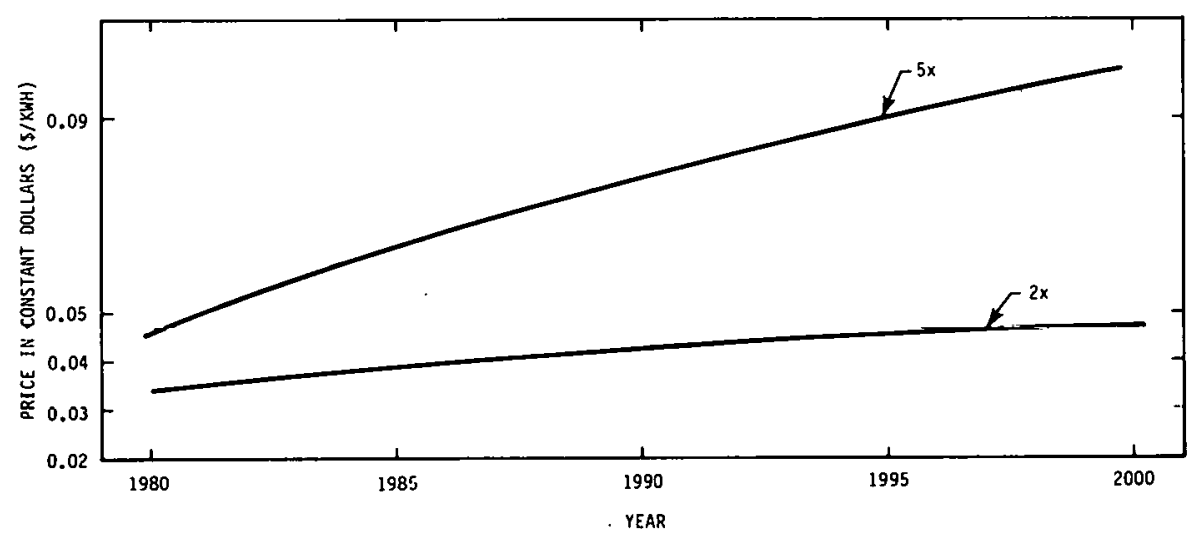

Figure 11. Electrical Energy Price Rise Plediclions

Table 11

Levelled Annual Energy Cost for ElectricHeated, Standard Metal Building

Fuel Cusl Esciálátión Rate

$2 \mathrm{X}$

$5 \mathrm{X}$
Inflation Räe $6 \%$ $12 \%$ $\$ 433.34 \$ 782.29$

$\$ 762.15 \$ 1427.43$ 
Comparing the levelled capital cost for the solar option, $\$ 529.86$, with the levelled fuel costs for the standard building shows that the solar option is an economically justified choice in all cases except one: the case of combined low inflation rate and low energy cost escalation.

\section{Performance}

Temperature measurements were made at the assembly building to determine the actual building performance. The inside air temperature was measured by a thermocouple on the north side of the building. This thermocouple was shielded from the water wall so that radiation from the water wall would not affect the measurement. The outside ambient temperature was measured by a thermocouple (shielded from the sun) located on the north side of the building. Measurements were recorded on a chart recorder approximately every $20 \mathrm{~min}$ from December 1979 to January 1980. Samples of the recorded data are shown in Figures 12 and 13 . The solar input scale in Figure 12 is uncalibrated. In Figure 13 the solar input is the record from a calibrated pyranometer (Eppley PSP) mounted between the windows on the south wall.

An analysis of the ambient temperatures showed there were 489 degree days at base temperature $10^{\circ} \mathrm{C}\left(50^{\circ} \mathrm{F}\right)$ during December 1979 and 420 degree days during January 1980 . The number of hours within each $5^{\circ} \mathrm{F}$ temperature bracket is shown in Figures 14 and 15 .

Solar radiation data were obtained from the U. S. Weather Bureau located at the Albuquerque airport, only a few miles from the solar. facility location. Because of equipment failures, some of the daily total horizontal radiation measurements were missing. Estimates for these missing measurements were made based on the percent sunshine measurements which were available for the entire month. 


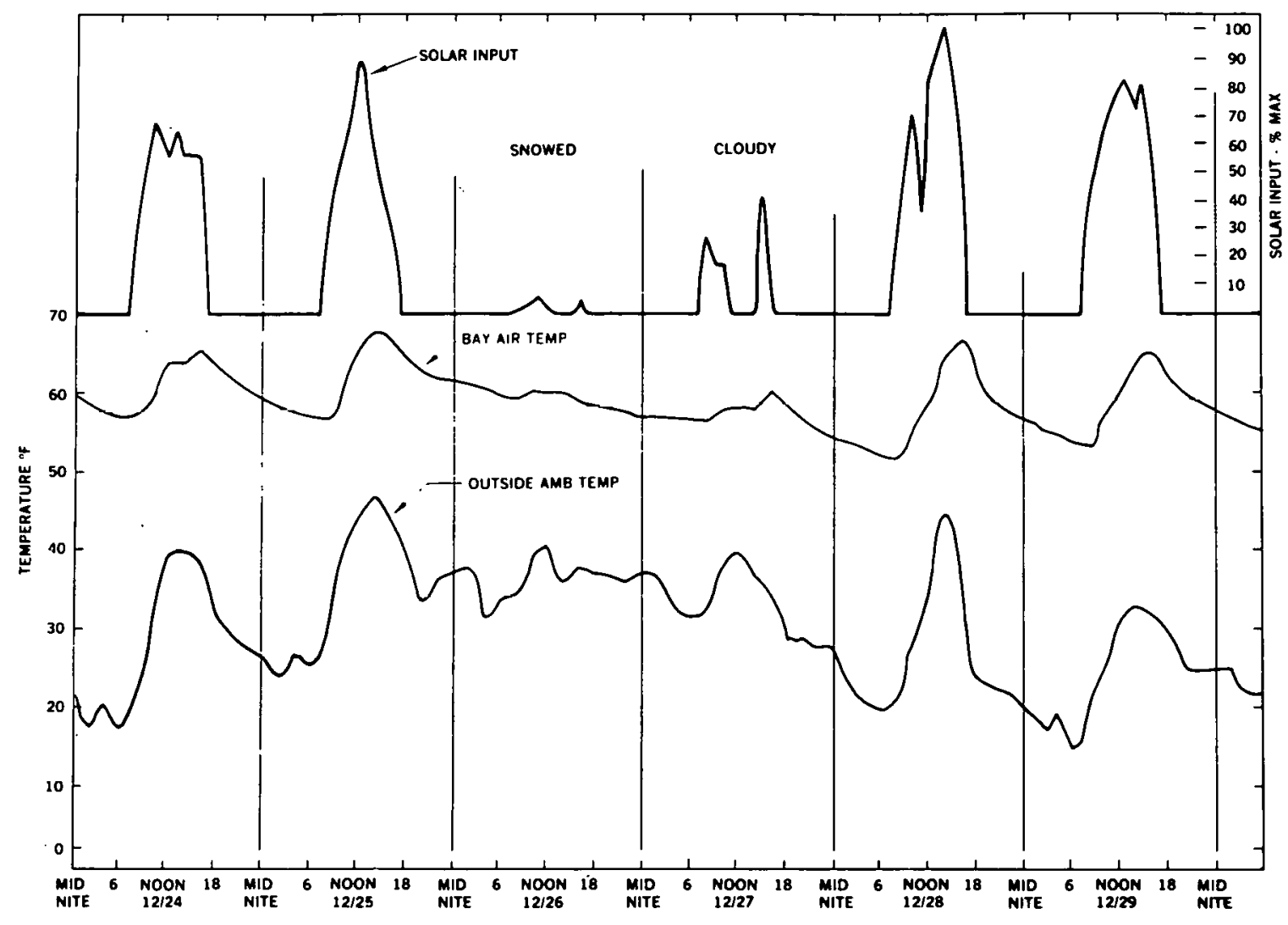

Figure 12. Data Recorded at Assembly Building, December 24-29, 1979

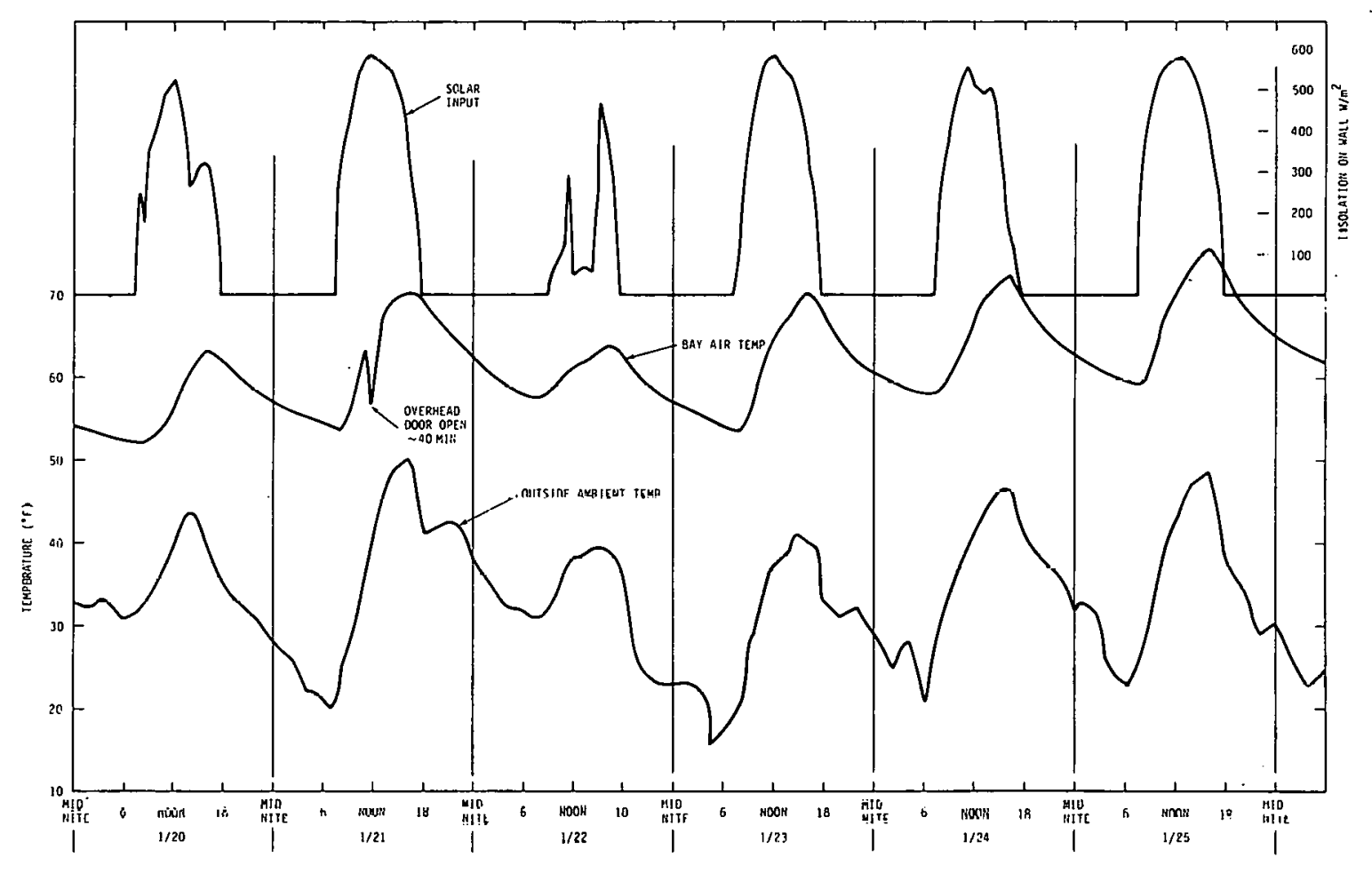

Figure 13. Data Recorded at Assembly Building, January 20-25, 1980. 


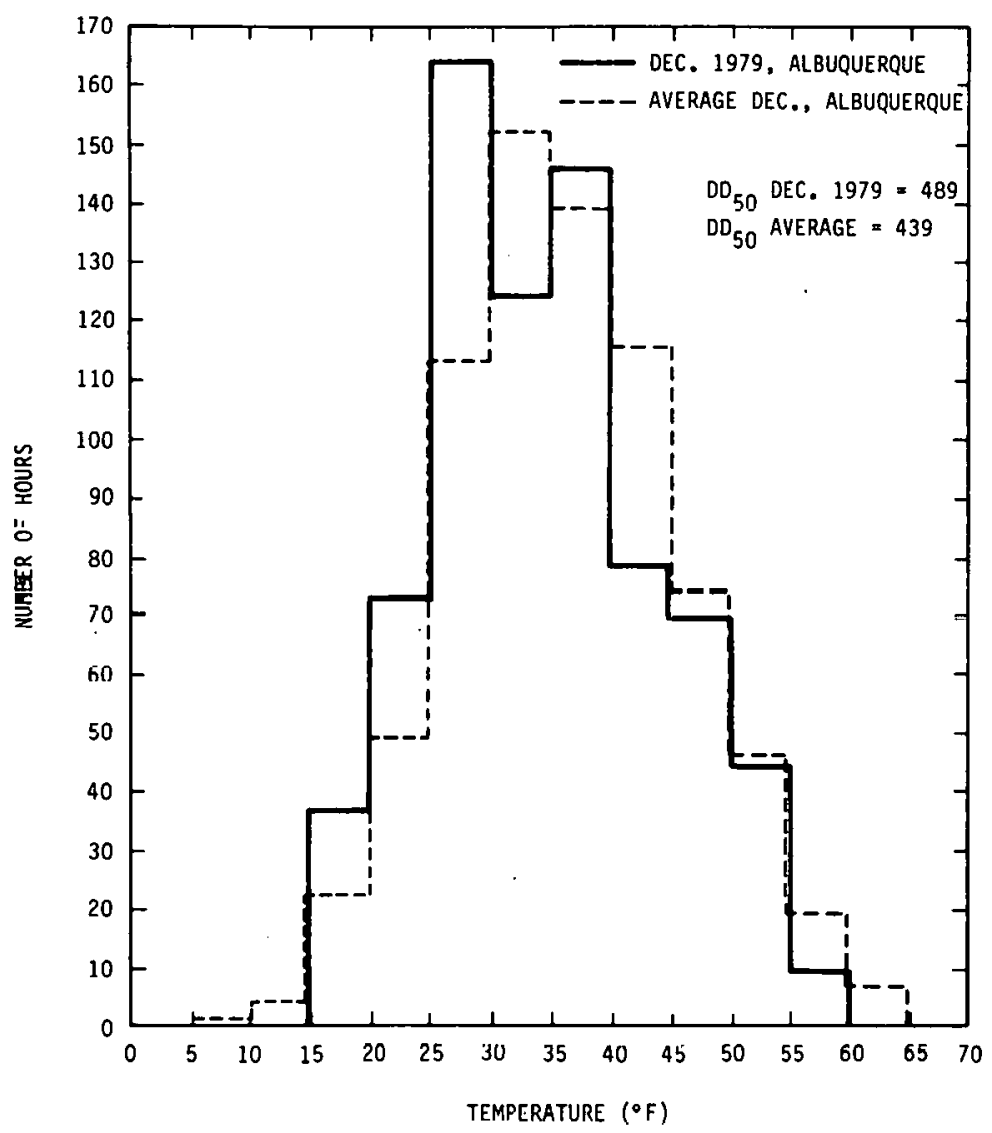

Figure 14

Number of Hours With1n Each $5^{\circ} \mathrm{F}$ Temperaturc Brackot tor Desember 1979

Figure 15

Number of Hours Within Each $5^{\circ} \mathrm{F}$ Temperature Bracket for January 1980

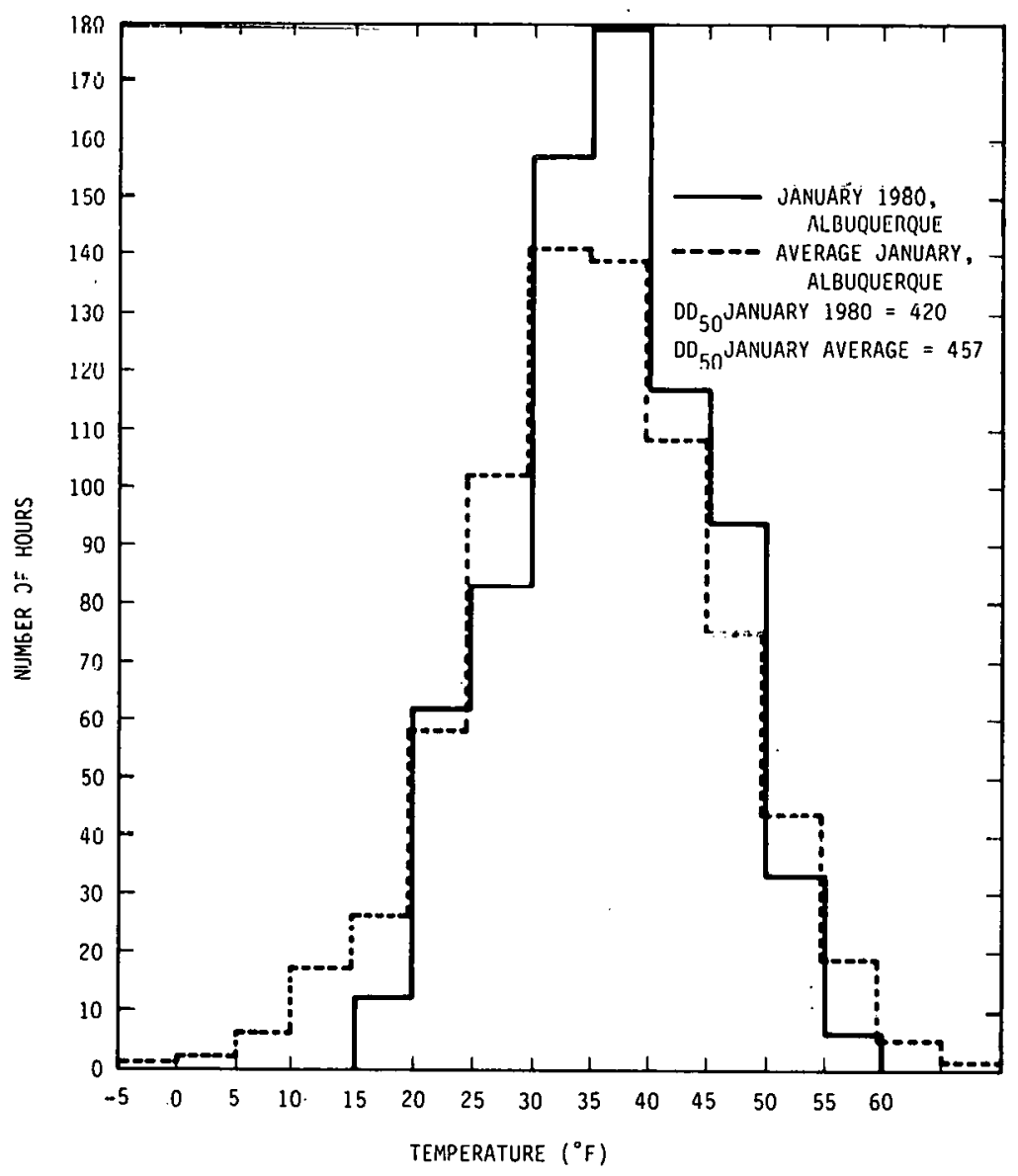


With the above figures as input data, the solar heating fraction for the month of December 1979 and January 1980 were computed. The results are shown in Table 12.

Table 12

Computation of Solar Heating Fraction

for December 1979 and January 1980

\begin{tabular}{|c|c|c|}
\hline & $\begin{array}{l}\text { Dec } \\
1979 \\
\end{array}$ & $\begin{array}{l}\text { Jan } \\
1980 \\
\end{array}$ \\
\hline Degree days, ${ }^{\circ} \mathrm{C}$ & $\begin{array}{c}272 \\
(489)\end{array}$ & $\begin{array}{l}233 \\
(420)\end{array}$ \\
\hline $\begin{array}{r}\text { Monthly load, } \mathrm{kWh} / \mathrm{mo} \\
(\mathrm{MBtu} / \mathrm{mo})\end{array}$ & $\begin{array}{r}2,186 \\
(7.46)\end{array}$ & $\begin{array}{r}1,878 \\
(6.41)\end{array}$ \\
\hline 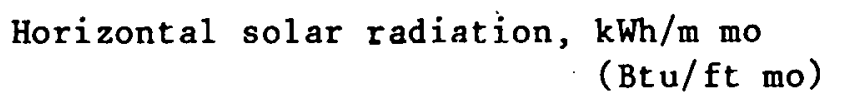 & $\begin{array}{l}86.1 \\
(27,288)\end{array}$ & $\begin{array}{l}78.73 \\
(24,957)\end{array}$ \\
\hline Latitude minus declination, deg & 58.18 & 56.50 \\
\hline $\begin{aligned} & \text { Solar radiation absorbed, } \mathrm{kWh} / \mathrm{mo} \\
&(\mathrm{MBtu} / \mathrm{mo})\end{aligned}$ & $\begin{array}{r}3,305 \\
(11.28)\end{array}$ & $\begin{array}{r}3,118 \\
(10.64)\end{array}$ \\
\hline Solar load ratio & 1.51 & 1.66 \\
\hline Solar heating fraction & 0.76 & 0.80 \\
\hline $\begin{aligned} \text { Auxiliary heating required, } & \mathrm{kWh} / \mathrm{mo} \\
& (\mathrm{MBt} \mathrm{u} / \mathrm{mo})\end{aligned}$ & $\begin{array}{r}524 \\
(1.79)\end{array}$ & $\begin{array}{r}375 \\
(1.28)\end{array}$ \\
\hline
\end{tabular}

These results indicate that auxiliary heating should have been required to keep the building temperature above $10^{\circ} \mathrm{C}\left(50^{\circ} \mathrm{F}\right)$ or, because no furnace was installed, the room temperature should have dropped below $10^{\circ} \mathrm{C}$ $\left(50^{\circ} \mathrm{F}\right)$. A review of the temperature records shows that the room air temperature did not go below $10^{\circ} \mathrm{C}\left(50^{\circ} \mathrm{F}\right)$ at any time during these months; the minimum temperature was $10.6^{\circ} \mathrm{C}\left(51^{\circ} \mathrm{F}\right)$. The unexpectedly efficient performance of the passive solar heating system can probably be attributed mainly to the high thermal mass of the water wall and to the added thermal mass of the bare concrete floor. 
The December 1979 weather characteristics (increased degree days and reduced solar insolation) are a severe test of a passive solar heating sys. tem. The ambient temperature data show that no severely cold days occurred in December 1979. However, in New Mexico severe cold is accompanied by clear weather and high insolation, and the assembly building heating system responds favorably to such conditions as shown by the January 1980 performance data.

The performance data confirm the practicality of the passive solar heating system for the photovoltaic facility assembly building. 
APPENDIX A

Method of Correction for Change in Ground Reflectance 


\section{APPENDIX A}

Method of Correction for Change in Ground Reflectance

\section{SYMBOLS}

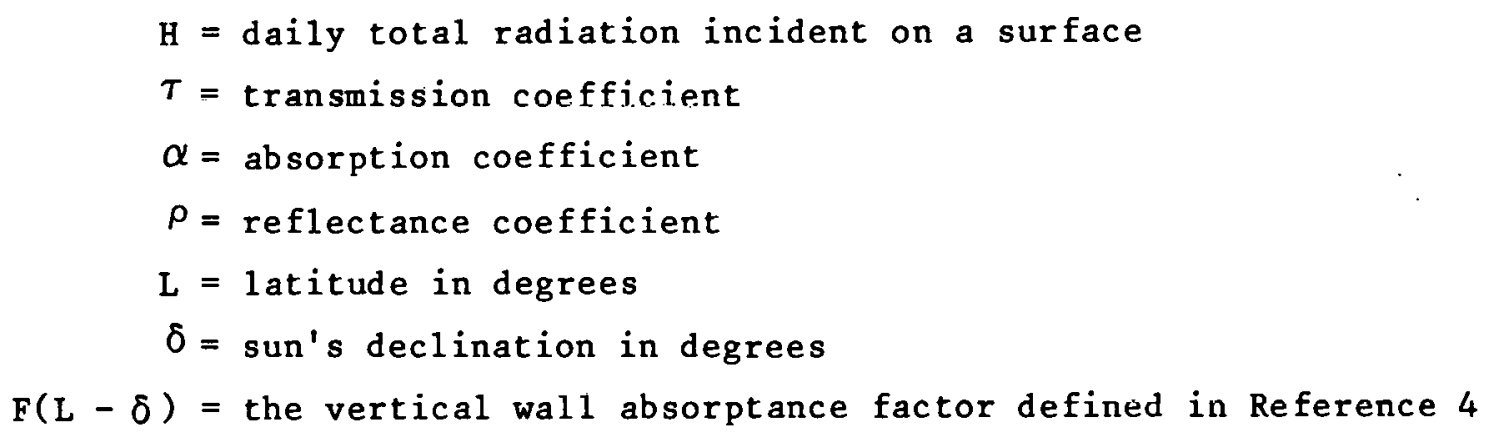

\section{SUB SCRIPTS}

FIRST SUBSCRIPT

$$
\begin{aligned}
& \text { D -- indicates direct radiation } \\
& \text { d -- indicates diffuse radiation } \\
& \text { r -- indicates reflected radiation } \\
& \mathrm{T}-- \text { indicates total radiation } \\
& \mathrm{g}-\mathrm{m} \text { indicates ground }
\end{aligned}
$$

SECOND SUBSCRIPT

$$
\begin{aligned}
& \text { h -- indicates horizontal surface } \\
& \text { v -- indicates vertical surface }
\end{aligned}
$$

The total radiation on a vertical surface, $H_{T v}$, is

$$
\mathrm{H}_{\mathrm{TV}}=\mathrm{H}_{\mathrm{Dv}}+\mathrm{H}_{\mathrm{dv}}+\mathrm{H}_{\mathrm{rv}} \text {, }
$$


where

$$
\mathrm{H}_{\mathrm{dv}}=1 / 2 \mathrm{H}_{\mathrm{dh}} \text { and } \mathrm{H}_{\mathrm{rv}}=1 / 2 \rho_{\mathrm{g}} \mathrm{H}_{\mathrm{Th}} \text {; }
$$

$$
\mathrm{H}_{\mathrm{Tv}}=\mathrm{H}_{\mathrm{Dv}}+1 / 2 \mathrm{H}_{\mathrm{dh}}+1 / 2 \rho_{\mathrm{g}} \mathrm{H}_{\mathrm{Th}} \text {. }
$$

$F(L-\delta)$ is defined as

$$
\mathrm{F}\left(\begin{array}{ll}
\mathrm{L} & \delta
\end{array}\right)=\frac{\tau \alpha \mathrm{H}_{\mathrm{Tv}}}{\mathrm{HTh}},
$$

where

$$
T=\text { frartinn transmittod }
$$

and

$$
\alpha=1
$$

The energy transmitted through the glazing and absorbed is

$$
\mathrm{F}(\mathrm{L}-\delta) \mathrm{H}_{\mathrm{Th}}=\tau \mathrm{H}_{\mathrm{TV}}=\tau_{\mathrm{D}^{\mathrm{H}} \mathrm{DV}}+\tau_{\mathrm{d}}\left(1 / 2 \mathrm{H}_{\mathrm{dh}}+\tau_{\mathrm{d}}\left(1 / 2 \rho_{\mathrm{g}} \mathrm{H}_{\mathrm{Th}}\right),\right.
$$

where

$$
\begin{aligned}
\tau_{D}= & \text { transmittance of direct radiation and is dependent on } \\
& \text { angle of incidence }
\end{aligned}
$$

and

$$
\tau_{d}=\text { transmittance of diffuse radiation. }
$$

Reflection is assumed to be diffuse reflection, not specular. Reference 4 used $\rho_{g}=0.3$ for the ground reflectance. If the ground reflectance is changed to $\rho_{g}$, then the energy transmitted through the glazing is

$$
\mathrm{F}^{\prime}(\mathrm{L}-\delta) \mathrm{H}_{\mathrm{Th}}=\tau_{\mathrm{D}^{\mathrm{H}}} \mathrm{H}_{\mathrm{v}}+\tau_{\mathrm{d}}\left(1 / 2 \mathrm{H}_{\mathrm{dh}}\right)+\tau_{\mathrm{d}}\left(1 / 2 \rho_{\mathrm{g}}^{\prime} \mathrm{H}_{\mathrm{Th}}\right)
$$


The difference in energy absorbed by the wall due to a change in ground reflectance is

$$
F(L-\delta) H_{T h}-F^{\prime}(L-\delta) H_{T h}=1 / 2 \tau_{d} H_{T h}\left(0.3-\rho_{g}^{\prime}\right),
$$

which gives

$$
F^{\prime}(L-\delta)=F(L-\delta)-1 / 2 \tau_{d}\left(\rho_{g}-\rho_{g}^{\prime}\right)
$$

for

$$
\begin{aligned}
& \rho_{g}^{\prime}=0.05(\text { black asphalt }) \\
& \tau_{d}=0.70 \text { (estimated hemispherical diffuse transmittance for } \\
& \text { standard suNWALL }
\end{aligned}
$$


APPENDIX B

Cost Evaluation Method 


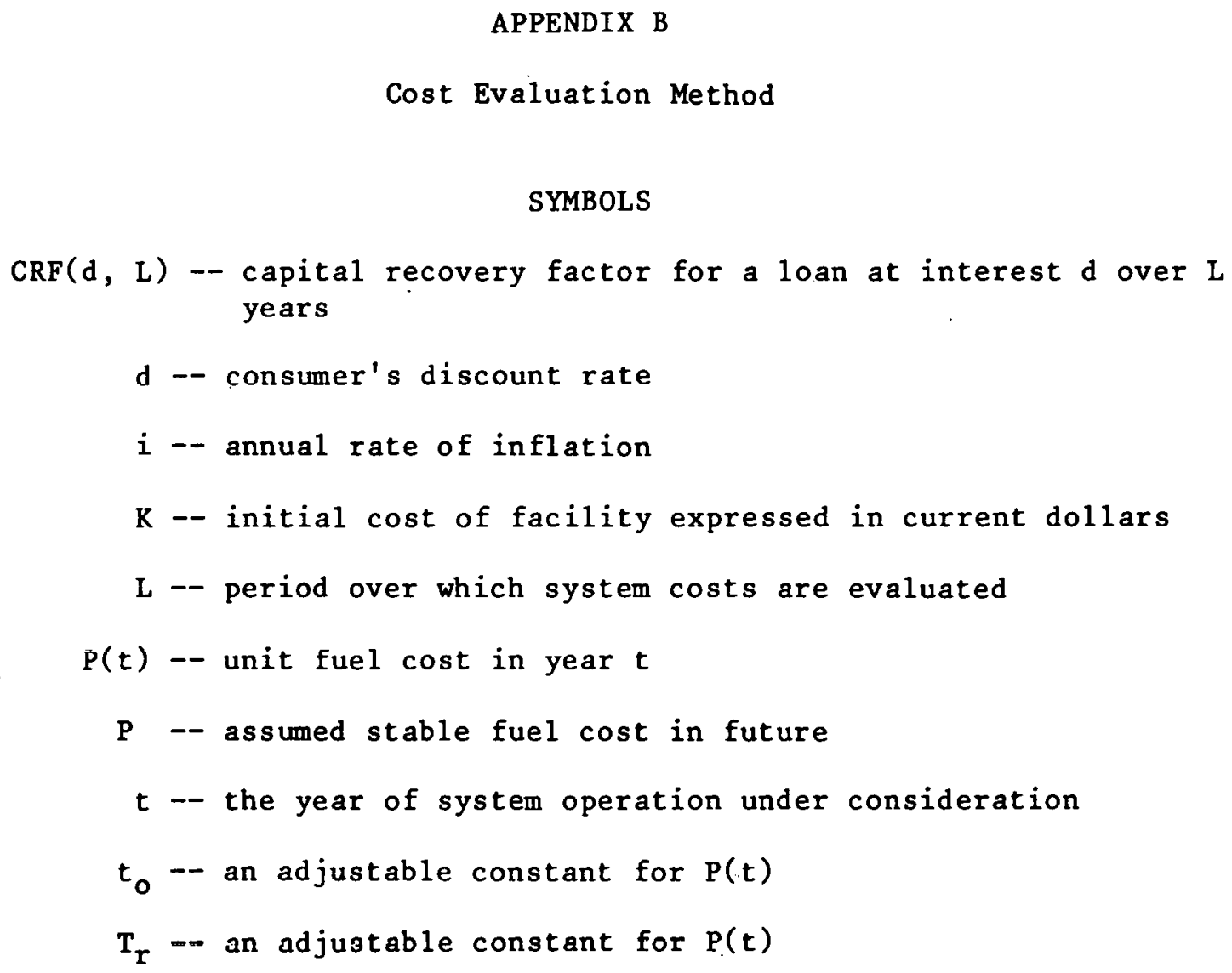

The "capital recovery factor," $\operatorname{CRF}(\mathrm{d}, \mathrm{L})$, is the ratio between the annual payments on a loan and the initial value of the loan if it is for $L$ years and pays an interest rate $d$.

$$
\operatorname{CRF}(d, L)=\frac{d(1+d)^{L}}{(1+d)^{L}-1}
$$

The levelized annual capital cost $=\operatorname{CRF}(d, L) \times K$ where $K$ is the initial cost. 
The form used to predict fuel cost, $P(t)$, is

$$
P(t)=P_{\infty}\left[1-\exp \left(\frac{t_{0}-t}{T_{r}}\right)\right]
$$

For the $2 \mathrm{X}$ fuel cost escalation model, the values for the parameters are

$$
\begin{aligned}
& P=0.0608(\$ / \mathrm{kWh}), \\
& t_{O}=1956.4, \text { and } \\
& T_{R}=28.334 .
\end{aligned}
$$

For the $5 \mathrm{X}$ fuel cost escalation model, the values of the paramerers are

$$
\begin{aligned}
& r \equiv 0.1522(\$ / \mathrm{kWh}), \\
& t_{0}=1969.7, \text { and } \\
& \mathrm{T}_{\mathrm{R}}=28.334 .
\end{aligned}
$$

The value of $\mathrm{P}(1976)$ is $\$ 0.03044$ for both the $2 \mathrm{X}$ model and the $5 \mathrm{X}$ model. The year 1976 is the base year. Fuel costs given by this model are expressed in constant 1976 dollars.

The levelized annual fuel cost, $P_{L}$, is found from

$$
P_{L}=\operatorname{CRF}(d, L) \sum_{t=1}^{T} P(t)\left(\frac{1+i}{1+d}\right)^{t} \text {. }
$$

This appendix was extracted from Reference 5. 
References

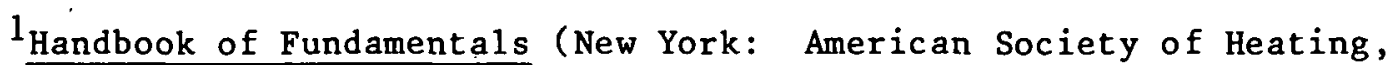
Refrigerating, and Airconditioning Engineers, 1977).

2 T. Kusuda and K. Ishii, Hourly Solar Radiation Data for Vertical and Horizontal Surfaces on Average Days in the United States and Canada, U. S. Department of Commerce, NBS Building Science Series 96 (Washington, D.C.: Government Printing office, 1977).

${ }^{3}$ Engineering Weather Data, Department of the Army Technical Manual 5785 (washington, D.C.: Government Printing office, 1978).

${ }^{4}$ J. D. Balcomb and R. D. McFarland, A Simple Empirical Method for Estimating the Performance of a Passive Solar Heated Building of the Thermal Storage Wall Type, LA-UR-78-1159 (Los Alamos, NM: Los Alamos Scientific Laboratory, 1978).

${ }^{5}$ U. S., Congress, Office of Technology Assessment, Application of Solar Technology to Today's Energy Needs (Washington, D.C.: Government Printing Office, September 1978). 
DISTRIBUTION :

TID-4500-R68 UC-62b (333)

American Section of the International

Solar Energy Society, Inc.

P. 0. Box 1416

Killeen, TX 76541

Attn: J. Kincel

Honorable Pete V. Domenici

Room 405

Russell Senate office B1dg.

Washington, D. C. 20510

\section{EPRI}

3412 Hillview Avenue

Palo Alto, CA 94303

Attn: J. E. Bigger

Georgia Institute of Technology

At lanta, GA 30332

ALLu: J. D. Walton

Georgia Power Company

At lanta, GA 30302

Attn: Mr. W. Hensley

Vice President Economics Services

Green Mountain Homes

Royalton, VT 05068

Attn: J. Kachadorian

Mike Hansen

Pecos Benedictine Abbey

Pecos, New Mexico 87552

Bruce Hunn

300 Valle Del Sol

Los Alamos, New Mexico 87545

Mark Jones

P. U. Box 892

Santa Fe, New Mexico 87501

Kalwall Corp.

P. O. Box 237

Manchester, N.H. 03105

Attn: S. Keller

Lawrence Berkeley Laboratory

University of California

Berkeley, CA 94720

Attn: M. Wallig
Lawrence Livermore Laboratory

University of California

P. 0. Box 808

Livermore, CA 94500

Attn: W. C. Dickinson

Los Alamos Scientific Laboratory

Los Alamos, NM 87545

Attn: J. D. Balcomb

C. D. Bankston

D. P. Grimmer

S. W. Moore

R. D. Mc Farland

Honorable Manuel Lujan

1324 Longworth Builiting

Washington, D. C. 20515

New Mexico State University (5)

Las Cruces, NM 88001

Attn: E. Lumsdaine

H. Zwibel (NMSEI)

Office of Technology Assessment

01d Immigration B1dg., Rm. 722

119 D. Street, N. E.

Washington, D. C. 20002

Attn: H. Kelily

One Design, Inc.

Mountain Falls Route

Winchester, VA 22601

Attn: T. J. Maloney

Parallax, Inc.

P. O. Box 180

Hinesburg, VT 05461

Attn: D. C. Taff

Honorable Harold Runnels

1535 Lungworth Building

Washington, D. C. 20515

Honorable Harrison H. Schmitt

Room 1.251

Dirksen Senate office Bldy.

Washington, D. C. 20510

Shepley Bulfinch Richardson \& Abbott

1 Court Street

Boston, MA 02108

Attn: G. W. Zwart 
New Mexico Engineering Research Institute University of New Mexico

P. 0. Box 25

Albuquerque, NR? 87131

Attn: G. Leigh

Solar Energy Research Institute

1536 Cole Blvd.

Golden, CO 80401

Attn: C. J. Bishop

$\mathrm{K}$. Brown

B. L. Butler

K. Haggard

M. Holtz

F. Kreith

C. Grosskreutz

B. P. Gupta

A. Rab1

Library (2)

TEA, Inc.

Church Hill

Harrisville, NH 03450

Attn: B. Anderson

Tech Reps, Inc. (10)

540 Chama, N.E., Suite 1

Albuquerque, NM 87108

Thayer School of Engineering

Dartmouth College

Hanover, NH 03755

Attn: A. O. Converse

Office of Solar Applications (4)

for Buildings

U. s. Department of Energy

Washington, D. C. 20545

U. S. Department of Energy (5)

Albuquerque Operations office

P. 0. Box 5400

Albuquerque, NM 87115

Attn: B. Barattino

U. S. Department of Energy (50)

Division of Passive Heating and Cooling

20 Massachusetts Avenue

Washington, D. C. 20585

U. S. Department of Energy

Division of Photovoltaics

Energy Systems

Washington, D. C. 20545

University of New Mexico (2)

Department of Mechanical Engineering Albuquerque, NM 87113

Attn: W. A. Cross

M. W. Wilden

Edward Maeria \& Associates

400 San Felipe Rd, NW

Albuquerque, NM

1000

1100

1230

1232

1472

1500

1540

1550

1552

1714

1714

2300

2320

2323

2326

2532

2533

3161

3162

3600

3650

3651

3652

3700

4000

4200

4231

4311

4332

4337

4362

4500

4700

4710
G. A. Fowler

C. D. Broyles

W. L. Stevens

S. D. Spray

L. G. Rainhart

W. A. Gardner

R. L. Brin.

F. W. Neilson

O. J. Burchett

R. E. Reed

B. G. Prentice

J. C. King

K. Gillespie

C. M. Gabriel

G. M. Heck

R. A. Hayenga

J. K. S. Walters, Jr.

J. E. Mit.chel1

C. J. Mora

R. W. Hunnicutt

At 11 : H. H. Pastorius, 3640

R. E. Hepplewhite

S. L. Johnson

V. O. Ealey

J. C. Strassell

A. Narath

G. Yonas

J. H. Renken

W. J. Shock

J. M. Parvin

W. C. Nickell

W. W. Wagoner

E. H. Beckner

J. H. Scott

G. E. Brandvold 
DISTRIBUTION：（cont）
4713 B. W. Marsha11
4714 R. P. Stromberg
4715 R. H. Braasch
4719 D. G. Schueler
4719 D. E. Haskins (25)
4720 V. L. Dugan
4721 J. V. Otts
4722 J. F. Banas
4723 W. P. Sch immel
4725 J. A. Leonard
1725 F. F. Rush
4730 H. M. Stoller
4740 R. K. Traegcr
8100 W. J. Spencer
8112 J. D. Gilson
8200 A. N. Blackwe 11
8250 L. E. Davies
8400 L. Gutierrez
8450 R. C. Wayne
8452 A. C. Skinrood
8453 W. G. Wilson
8266 E. A. Aas
3141 T. L. Werner (5)
3151 W. L. Garner (3)
for DOE/TIC (Unlimited Release) 


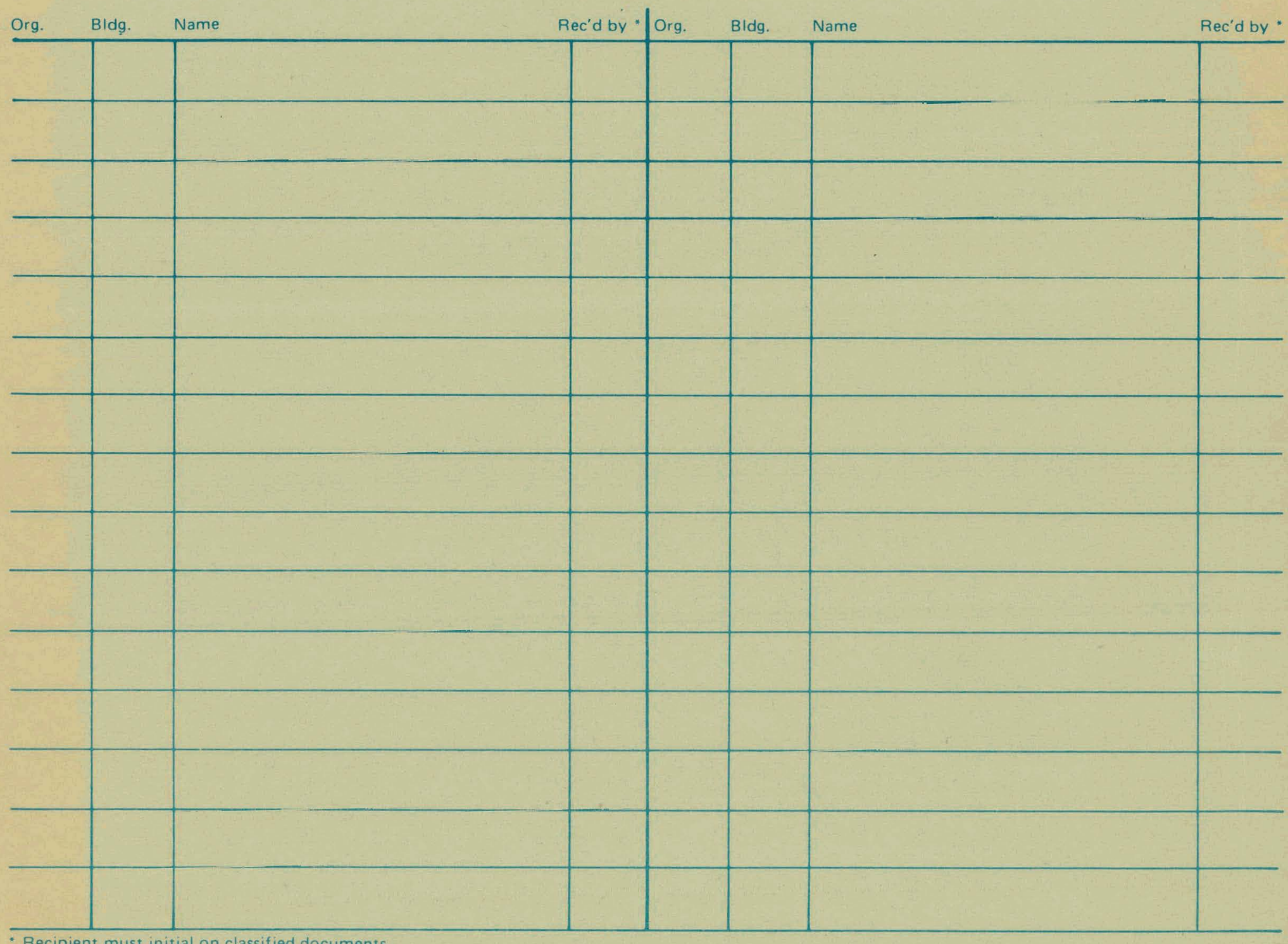

* Recipient must initial on classified documents. 